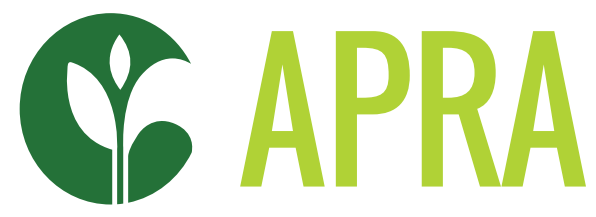

Agricultural Policy Research in Africa

\title{
POLITICAL ECONOMY OF THE OIL PALM VALUE CHAIN IN GHANA \\ Kofi Takyi Asante
}




\section{CONTENTS}

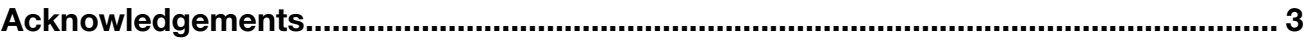

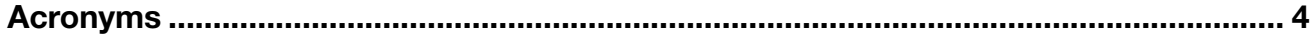

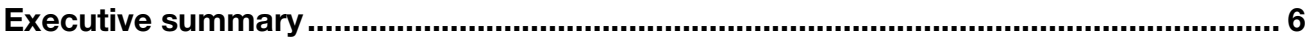

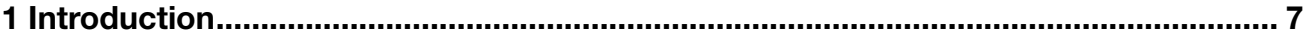

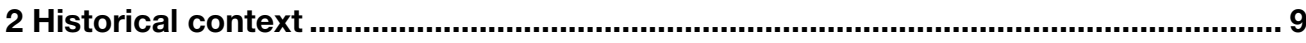

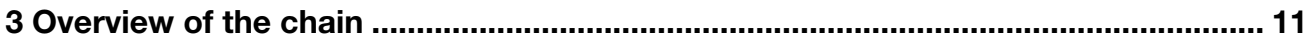

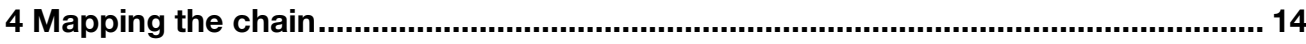

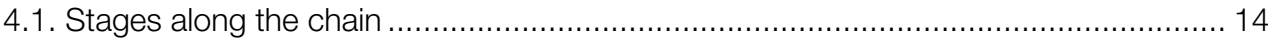

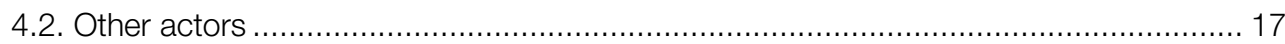

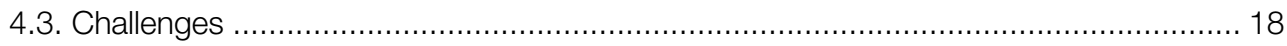

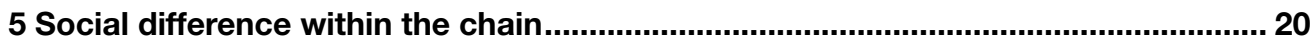

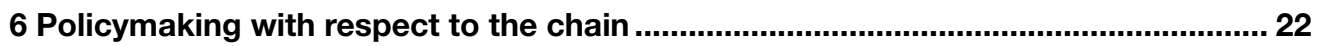

6.1. From early independence to period of crisis....................................................... 22

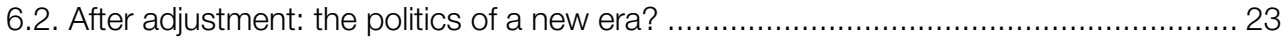

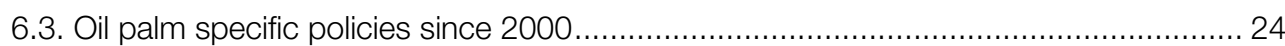

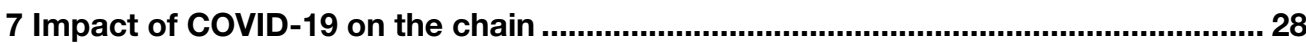

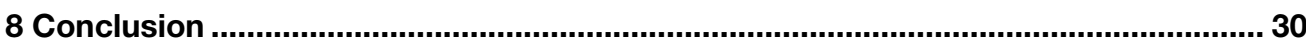

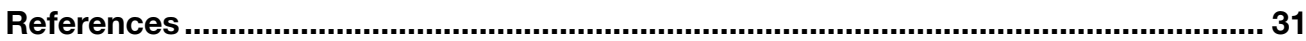

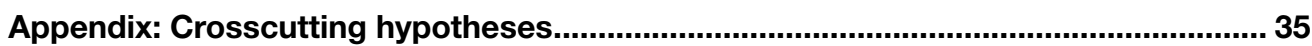

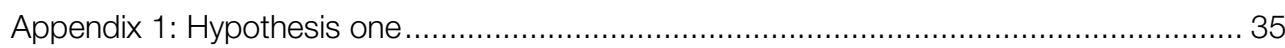

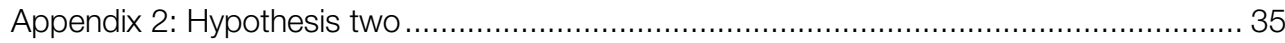

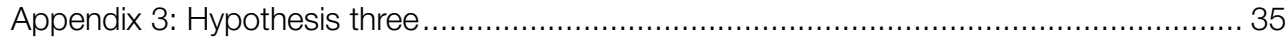

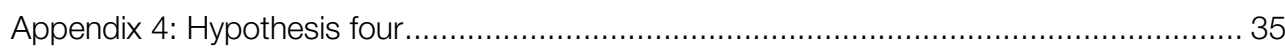

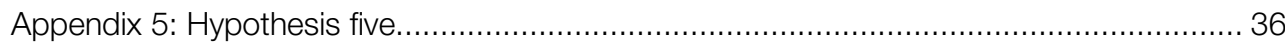

\section{Tables}

Table 3.1 Annual area planted to selected crops, ('O0Os ha)......................................... 11

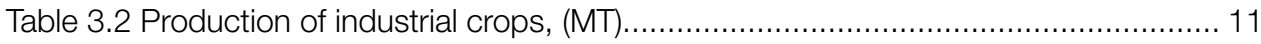

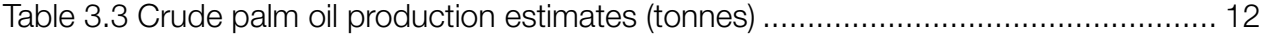

Table 6.1 Summary of Ghana's political and economic regimes ..................................... 25

Table A1 Population densities in oil palm growing areas .............................................. 36

\section{Figures}

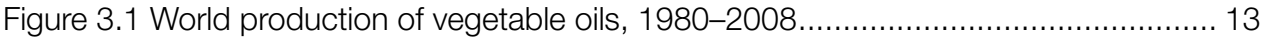

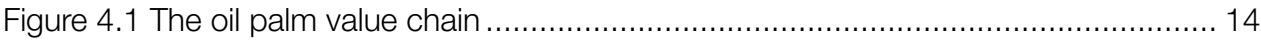

Figure 4.2 Area under estates and independent smallholdings....................................... 15 


\section{ACKNOWLEDGEMENTS}

This research was conducted under the Agricultural Policy Research in Africa (APRA) programme. The author would like to acknowledge the financial and technical support from the Institute of Development Studies (IDS).

Kofi Takyi Asante is a research fellow at the Institute of Statistical, Social and Economic Research at the University of Ghana.

This working paper is funded with UK aid from the UK government (Foreign, Commonwealth \& Development Office - FCDO, formerly DFID). The opinions are the authors and do not necessarily reflect the views or policies of IDS or the UK government. 


\section{ACRONYMS}

ADB

AFD

APRA

BOPP

COVE

CPO

CSIR

cso

ERP

FAO

FFA

FFB

FSP

GOPDA

IMF

NDC

NBSSI

NOPL

NPP

OPDAG

PERD

PFJ

PNDC
Agricultural Development Bank

Agence Française de Développement

Agricultural Policy Research in Africa

Benso Oil Palm Plantation

corporate village enterprise

crude palm oil

Council for Scientific and Industrial Research

civil society organisation

economic recovery programme

Food and Agriculture Organization

free fatty acids

fresh fruit bunch

fertiliser subsidy programme

Ghana Oil Palm Development Association

International Monetary Fund

National Democratic Congress

National Board for Small Scale Industries

National Oil Palm Limited

New Patriotic Party

Oil Palm Development Association of Ghana

Planting for Export and Rural Development

Planting for Food and Jobs

Provisional National Defence Council 


$\begin{array}{ll}\text { PPP } & \text { public-private partnership } \\ \text { OPRI } & \text { Oil Palm Research Institute } \\ \text { PKO } & \text { palm kernel oil } \\ \text { PPPC } & \text { Programme for the Promotion of Perennial Crops } \\ \text { PSI-Oil Palm } & \text { President's Special Initiative on Oil Palm } \\ \text { RSPO } & \text { Roundtable on Sustainable Palm Oil } \\ \text { SME } & \text { small and medium enterprises } \\ \text { SRID } & \text { Statistics, Research and Information Directorate } \\ \text { SWAPP } & \text { Sustainable West African Oil Palm Programme } \\ \text { TCDA } & \text { Tree Crop Development Authority }\end{array}$




\section{EXECUTIVE SUMMARY}

Oil palm (Elaeis guineensis) is of strategic importance to the Ghanaian economy. It is the second most important industrial crop after cocoa and is used widely in local food preparation as well as in industrial processing. In spite of its importance, however, oil palm has consistently underperformed since the early twentieth century. This paper conducts a value chain analysis of the crop, foregrounding the political economy factors that shape the performance of the sector. It draws on a combination of in-depth interviews conducted in March 2020 with a variety of value chain actors and a review of the secondary literature. Additionally, between late May and early June 2020, twelve further interviews were conducted as part of a rapid market survey to assess the impact of the COVID-19 pandemic on the value chain.

The oil palm industry in Ghana serves two distinct markets, namely domestic consumption and industrial processing. The value chain, therefore, has two largely independent segments corresponding to the endmarket served. The industrial processing segment comprises large- and medium-scale plantations and processing mills. The estate plantations possess their own mills and process palm oil on their establishments. They have higher productivity because they enjoy the advantage of improved input, economies of scale, and superior technology. On the other hand, productivity in the home consumption segment, which is dominated by smallholders, is impeded by factors like low-yielding oil palm varieties, fragmented landholdings, and lowquality crude palm oil (CPO).

Even though the oil palm sector has enjoyed policy attention since at least the early twentieth century, and significantly more so since independence, growth in the industry continues to be weak. Since the return to constitutional rule in the 1990s, the logic of electoral competition within the context of limited economic development has increased the preference of political leaders for policies with immediate electoral payoffs. Additionally, policymakers are reluctant to make tough but necessary decisions regarding the sector or to stick to such decisions once they are made. Within this political economy context, policies designed to promote growth in the oil palm industry have failed to address longstanding structural barriers to productivity.
However, actors in both segments of the value chain express optimism that the Tree Crop Development Authority, launched in September 2020 (GOG 2020), will turn the fortunes of the industry.

The outbreak of the COVID-19 pandemic has affected every segment of the value chain. Falling world market prices for palm oil caused a reduction in farmgate prices for fruits. At the same time, domestic demand for palm oil dropped as eateries closed or reduced operations and border closures shut off access to subregional markets, prompting many agri-businesses along the chain to lay off workers and to substantially scale down production. 


\section{INTRODUCTION THE POLITICAL ECONOMY, VALUE CHAINS, AND INCLUSION}

As Ghana's second most important cash crop, oil palm (Elaeis guineensis) has strategic importance to the national economy. However, despite its significance, the oil palm sector has consistently underperformed and responded weakly to government incentives. In the nineteenth century, it was one of the most important export commodities from the Gold Coast, but since the turn of the twentieth century, production has been unable to meet the domestic demand. Successive governments have devoted a great deal of policy attention and resources to developing the oil palm sector as part of a broader agenda to stimulate industrial growth and to reduce rural poverty. This paper conducts a value chain analysis of the crop, highlighting the political economy factors that shape the performance of the sector, and the distribution of rewards among participants along the chain.

Value chain analyses are analytical, and political and pragmatic in nature. As an exercise, value chain analyses detail the steps involved in moving a commodity from the initial stages (e.g. nursing seedlings) to eventual delivery to consumers. The value chain also details the roles that various actors play at each stage of production. The political and pragmatic aspect has to do with identifying binding constraints that inhibit productivity, such as lack of access to improved seedlings or use of inefficient technology in cultivation. Stakeholders then come up with solutions to make the chain more efficient (Donovan et al. 2015; Prowse and Moyer-Lee 2014). In recent times, value chain analyses explicitly focus on issues of 'inclusivity' along the chain (Manley and Leynseele 2019; Shepherd 2016). Inclusive value chain analyses aim to promote a just social outcome by contributing to poverty reduction or women's empowerment (Donovan et al. 2015).

The political settlement perspective provides a useful framework for understanding the broad structural and relational factors that shape how particular value chains work. The political settlement approach is premised on the idea that enforcement of formal rules or policies is shaped by the social context within which such rules are implemented. This includes informal practices and the groups whose interests could be affected by any given policy intervention. The political settlement approach further emphasises that the social distribution of power rarely overlaps with formal institutional arrangements. Hence, studies that focus exclusively on the workings of formal institutions, or that construe informality as something unusual, fail to understand how policies are made and implemented in reality (Khan 2018). It is the incentive structures underpinning the interactions between formality and informality which drives the politics of development, as multiple case studies have confirmed (Behuria 2020; Appiah and Abdulai 2017; Asante 2012; Fold and Whitfield 2012).

In fact, the economist Mushtaq Khan, who developed the approach, is emphatic that a country's political settlement shapes the way its formal institutions work. Formal institutions impose different costs and generate different benefits for different groups. A policy to encourage production for export may divert state resources from supporting farmers who produce mainly for the domestic market. Accordingly, factions develop in response to these policies and the struggle over the distribution of rents resulting from any given institution or policy intervention. In democratic systems such as Ghana's, factions may be organised within political parties or as independent pressure groups or trade associations. When formulating policies or distributing resources, political leaders attempt to minimise the risks posed by factions that have the ability to cause 'real political trouble' (Burton and Higley 2001 cited in Hickey 2013). Ruling coalitions, therefore, consider this threat and, depending on the level of regime vulnerability, may respond in a variety of ways. This includes heavy-handed responses, conciliatory moves - via co-optation, rent distribution etc. - or ignoring the threat altogether.

If a policy proposal is likely to involve heavy losses for a social group or faction which is strong enough to mobilise credible opposition to the government, policymakers are likely to back down, or to make concessions to the affected groups. On the other hand, where productive forces, such as farmers, business groups, or manufacturers, are weak or unable to effectively mobilise substantial opposition, it is unlikely that policymakers will seriously consider their concerns when formulating policies. In these struggles, social groups who have "holding power", i.e. those who can absorb short-term losses while maintaining 
their position in the relative distribution of power, are more likely to win in the long-term (Khan 2018). These dynamics are apparent, some more so than others, in the organisation of Ghana's oil palm value chain and in the policies formulated to develop the chain.

This paper attempts to explain why the oil palm sector has consistently underperformed, in spite of successive governments prioritising the industry since colonialism ended. It does this through an analysis of the secondary literature, including reports, journal articles, and policy documents. This is supplemented with twelve interviews conducted in March 2020 with actors along the value chain, including producer associations, officials of the Ministry of Food and Agriculture, representatives of donor agencies, and officials of non-governmental organisations (NGOs) or civil society organisations (CSOs). Between late May and early June 2020, twelve additional interviews were conducted as part of a rapid market survey to assess the impact of the COVID-19 pandemic on the value chain.

The rest of the paper is structured as follows. The next section presents a historical account of the rise and continued decline of the oil palm value chain. The third section provides an overview of the industry, briefly describing its performance and contribution to the national economy. The fourth section maps the value chain, highlighting the challenges at each step of the chain and the lines of social difference and inequality within it. The fifth section discusses the wider political economy context within which policies targeting the industry have been framed since independence. The following section reflects on the impact of the COVID-19 outbreak on the value chain. In the conclusion, the paper returns to the question why an economic sector would consistently underperform even though it has had policy attention for decades. 
Palm oil production has been deeply enmeshed with economic and political developments in Ghana for centuries, but became politically important from the early decades of the nineteenth century. When the slave trade was abolished in 1807, the ensuing economic vacuum was filled by the so-called 'legitimate trade', consisting of the export of primary commodities like palm oil, groundnut, and ivory, and the import of manufactured goods from Europe. The advent of legitimate trade had such a important impact on social and political structures of nineteenth century West Africa, not least, the Gold Coast, that Hopkins (cited in Law 1995: 4) concluded that it was 'the start of the modern economic history of West Africa.' Legitimate commerce shifted the prevailing power dynamics by raising an influential class of men connected with the trade between West Africa and Europe (Asante 2018; Dumett 1983). Known as 'merchant princes', these traders became politically important allies to the emerging colonial state. However, they later transformed into an early protest movement, when they were gradually pushed to the margins of the colonial government, which by the end of the eighteenth century had grown more self-assured (Asante 2019).

Palm oil production and export became a major economic activity in the nineteenth century Gold Coast from the 1820s. Palm oil and palm kernels were the most important commodity exports and the largest source of export revenue for the colonial government during this period, in 1884 accounting for as much as 70 per cent of total exports from the colony (Howard 1978, cited in Gyasi 1992) until oil palm was eclipsed by the cocoa economy in the first decade of the twentieth century (Wilson 1990).

And yet, in spite of oil palm's centrality to the nineteenth century colonial economy, it was characterised by peasant production, with official policy having little influence on the value chain. At the start of legitimate commerce, oil palm was harvested in the wild but was subsequently cultivated by peasants in the hinterlands. Coastal-based merchants bought the processed palm oil in the inland areas, from where it was rolled in barrels to the coast for export.

Access to large tracts of land for plantation production was a politically sensitive matter. An attempt by the colonial government in 1896 and 1897 to vest 'unused' land in the hands of the colonial government sparked spontaneous protest and led to the formation of the first national protest movement in the colony (Kimble 1963). Stung by that experience, both metropolitan and local officials were reluctant to intervene further in land matters. This event turned out to be fateful by discouraging the colonial government from subsequent land tenure reforms, and ensured that small-scale or peasant farmers dominated the production of the main commercial crops (like oil palm, rubber, coffee, and subsequently cocoa). Furthermore, and in spite of the incentives created by later governments, plantations or formal estates accounted for only a small fraction of output (Fold and Whitfield 2012).

Thus, the emergence of oil palm as a backbone of the economy was independent of direct colonial policy intervention. Nevertheless, the oil palm industry had grown partly as a result of the presence of the colonial administration. Gyasi (1992) observes that even though the littoral belt lacked the ideal ecological features necessary for oil palm production, 'political instability and poor transportation in the interior' ensured that the belt did not extend too far from the coastal areas (see Hypothesis One in the Appendix). Its entire stretch of about $500 \mathrm{~km}$ from Dzodze in the east to Half Asini in the west ran parallel to the coastline where the colonial administration, as basic as it was, had some presence (Gyasi 1992: 42).

After a high point in 1884, the oil palm economy entered a phase of rapid decline due to a combination of factors, including plummeting world market prices for the commodity, felling of trees to produce palm wine, and growing political instability in the coastal and inland areas owing to greater intervention by the colonial government in the social and political affairs of the traditional states. This was further compounded by the fact that the principal African merchants were at this point increasingly being marginalised in the international trade as racial discrimination against the educated African elite intensified towards the end of the nineteenth century (Asante 2019; Gyasi 1992; Dummet 1983).

Belated attempts by the colonial government did little to stop the decline of the oil palm sector. This 
included efforts to incentivise estate production with the Oil Palm Ordinance of 1912, which allowed the government to award processing rights to all fruits produced within $16 \mathrm{~km}$ of a mill, and an arrangement under the 1929 General Scheme for Subsiding Palm Oil Factories, which subsidised large mills if fruits fell below five-sixths of processing capacity. In addition, starting from 1949, the government established oil palm service centres in interior regions such as Volta, Eastern, Central, Western, Ashanti, and Brong Ahafo, where ecological conditions were more favourable to oil palm production. The new oil palm belt that eventually emerged was concentrated along these service centres (Gyasi 1992). However, this was too little, too late, and palm oil exports continued to steadily decline until in 1955, when export ceased altogether (Gyasi 1992: 43). 


\section{OVERVIEW OF THE CHAIN}

Oil palm is one of ten industrial crops produced in Ghana. The oil palm industry is of strategic importance to the national economy. As the second most important industrial crop after cocoa, it makes a key contribution to agricultural development. The agricultural sector is integral to many African economies, including Ghana. Although agriculture's economic dominance has declined in recent years due to the expansion of the service sector, it still contributes significantly to economic growth in the country. For instance, agriculture employs over a third of the economically active population (GSS 2019; ISSER 2019). Moreover, between 2013 and 2018, the agricultural sector's average contribution to gross domestic product (GDP) was 21.6 per cent, with industry and services being
34.5 per cent and 43.9 per cent respectively (ISSER 2019). Agriculture also contributes significantly to the country's foreign exchange earnings, even though the cocoa sub-sector outperforms all other crops in this regard (ISSER 2019).

There is a lack of accurate data on the current state of the oil palm industry, a situation which partly reflects wider problems facing the industry. Producing companies are reluctant to share information that their competitors may take advantage of, or which could increase their tax liability (executive of OPDAG pers. comm. May 2020; and Statistics, Research and Information Directorate (SRID) of MoFA official pers. comm. May 2020). Available information on the current

Table 3.1: Annual area planted to selected crops, ('000s ha)

\begin{tabular}{|l|l|l|l|l|l|l|l|l|}
\hline Crop & 2011 & 2012 & 2013 & 2014 & 2015 & 2016 & 2017 & 2018 \\
\hline Cocoa & $1,600.30$ & $1,600.80$ & $1,650.80$ & $1,683.77$ & $1,717.44$ & $1,751.79$ & $1,786.83$ & $1,826.82$ \\
\hline Oil palm & 381.80 & 397.10 & 409.10 & 349.04 & 425.60 & 434.12 & 346.71 & 351.39 \\
\hline Cashew & 82.00 & 86.50 & 89.00 & 90.78 & 92.60 & 94.45 & 95.00 & 118.75 \\
\hline Coconut & 25.30 & 25.30 & 26.10 & 26.60 & 27.15 & 27.70 & 28.25 & 28.68 \\
\hline Rubber & 25.80 & 26.00 & 26.80 & 27.35 & 27.88 & 28.44 & 29.01 & 29.59 \\
\hline
\end{tabular}

Note: Figures are based on projections from Statistics, Research and Information Directorate Source: MoFA (2019a)

Table 3.2 Production of industrial crops (metric tonnes)

\begin{tabular}{|l|l|l|l|l|}
\hline Year & Cocoa & Coffee & Rubber & Oil palm \\
\hline $\mathbf{2 0 0 7 / 0 8}$ & 680,781 & 2,024 & 14,132 & $1,896,760$ \\
\hline $\mathbf{2 0 0 8 / 0 9}$ & 710,642 & 516 & 19,134 & $2,103,600$ \\
\hline $\mathbf{2 0 0 9 / 1 0}$ & 632,037 & 4,082 & n.a. & $2,004,300$ \\
\hline $\mathbf{2 0 1 0 / 1 1}$ & $1,024,554$ & 9,035 & n.a. & $2,125,645$ \\
\hline $\mathbf{2 0 1 1 / 1 2}$ & 879,348 & 48,517 & n.a. & $2,196,098$ \\
\hline $\mathbf{2 0 1 2 / 1 3}$ & 835,466 & 43,931 & n.a. & $2,334,400$ \\
\hline $\mathbf{2 0 1 3 / 2 0 1 4}$ & 896,220 & 45,093 & n.a. & $2,451,130$ \\
\hline $\mathbf{2 0 1 4 / 2 0 1 5}$ & 740,254 & 42,230 & n.a. & $2,529,513$ \\
\hline $\mathbf{2 0 1 5 / 2 0 1 6}$ & 778,043 & n.a. & n.a. & n.a. \\
\hline $\mathbf{2 0 1 6 / 2 0 1 7}$ & 969,500 & n.a. & n.a. & n.a. \\
\hline $\mathbf{2 0 1 7 / 2 0 1 8}$ & 904,790 & n.a. & n.a. & n.a. \\
\hline $\mathbf{2 0 1 8 / 1 9}$ & 919,577 & n.a. & n.a. & n.a. \\
\hline
\end{tabular}

Source: MoFA (2019a) 
state of the industry is based on baseline estimates from the Planting for Export and Rural Development (PERD) programme, which puts the land area under cultivation for 2018 at 420,000ha (MoFA SRID official pers. comm. May 2020). The area of land planted to oil palm has fluctuated over recent years, reaching a highpoint of 434,120 ha in 2016, before lowering to 346,710 ha in 2017, as shown in Table 3.1 below (MoFA 2019a).

Available data shows a slight year-on-year increase in the production of oil palm since the mid-2000s. Apart from an almost 100,000mt drop in production in 2009/10 production year, the oil palm sector has witnessed a steady increase in output, from $1,896,760 \mathrm{mt}$ in $2007 / 08$ to $2,529,513 \mathrm{mt}$ in $2014 / 15$. These figures, the last year when data was available, are an increase of about $700,000 \mathrm{mt}$. In comparison, cocoa output expanded from $680,781 \mathrm{mt}$ to $919,577 \mathrm{mt}$ during the same period (see Table 3.2).

Production of CPO has also consistently increased since the early 2000s. This expansion in production has been partially attributed to the effects of the privatisation of state-owned farms or estates following structural adjustment (Huddleston and Tonts 2007). In the period between 2006 and 2015, production grew by more than 204,000t. However, independent smallholders accounted for a huge bulk of the output. In fact, over the period, CPO production by estate mills has declined by 2,956t while smallholder production has almost doubled (see Table 3.3).

There is currently no accurate count of the total number of persons employed directly by the oil palm economy (SRID MoFA official pers. comm. May 2020; executives of Artisanal Palm Oil and OPDAG pers. comm. May
2020), but the Ghana Living Standards Survey gives the number of households who harvested oil palm as 119,724 (GSS 2019). It has also been estimated that, across the entire value chain, the industry generates over two million jobs in rural Ghana, and that expanding production to fill the domestic deficit alone could create additional 141,000 direct jobs (MASDAR 2011: 1.32-2.32).

If productive capacity is enhanced, oil palm producing countries in Africa stand to reap substantial gains due to growing demand for palm oil within the continent, and on the world market. Growing demand has been fuelled by a number of factors, including: population growth; rising prosperity and nutrition; and increasing demand for palm-based halal food products by Muslim populations. Furthermore, the shift from petroleum-based products and the search for alternative sources of fuels has further boosted global attention in the commodity. Recent applications include uses as feedstock in biofuel production and as an ingredient in the manufacture of detergents, surfactants, pharmaceuticals, and nutraceuticals (MASDAR 2011).

There is a large demand for CPO for home consumption in Ghana. Over half of all Ghanaian households use palm oil as an ingredient in food preparation, although this is less prevalent in the northern parts of the country, where shea butter is used as a substitute (MASDAR 2011). The rate of growth in consumption, about 2.4 per cent per annum, has been closely linked to population growth, and demand was estimated at 379,000mt in 2011 (MASDAR 2011). Because of the high demand for palm oil for domestic consumption, the industrial-use sector competes with the artisanal processing sector for FFBs. Industrial processors are, thus, dependent on imports

Table 3.3 Crude palm oil production estimates (tonnes)

\begin{tabular}{|l|l|l|l|l|l|l|l|l|l|l|}
\hline Companies & 2006 & 2007 & 2008 & 2009 & 2010 & 2011 & 2012 & 2013 & 2014 & 2015 \\
\hline GOPDC & $28,743.10$ & $17,842.70$ & $18,055.68$ & $20,143.00$ & $18,960.54$ & $18,045.80$ & $17,131.05$ & $16,216.30$ & $17,027.12$ & $17,476.16$ \\
\hline BOPP & $16,485.00$ & $15,305.00$ & $14,960.18$ & $14,124.00$ & $14,232.57$ & $13,916.82$ & $13,601.07$ & $17,554.00$ & $17,817.31$ & $18,173.66$ \\
\hline TOPP & $20,348.00$ & $14,797.10$ & $14,249.66$ & $17,373.00$ & $14,544.40$ & $13,627.94$ & $12,711.48$ & $11,795.02$ & $11,971.95$ & $12,930.16$ \\
\hline NGL (NOPL) & $7,019.00$ & $7,721.00$ & $8,492.83$ & $12,775.00$ & $11,812.93$ & $12,856.74$ & $13,900.55$ & $14,944.36$ & $15,168.53$ & $15,579.07$ \\
\hline AMEEN & $9,805.00$ & $10,785.50$ & $11,863.68$ & $11,000.00$ & $12,589.86$ & $13,314.50$ & $14,039.14$ & $14,763.78$ & $14,985.24$ & $15,284.94$ \\
\hline $\begin{array}{l}\text { Sub-total } \\
\text { S2,400.10 }\end{array}$ & $66,451.30$ & $67,622.03$ & $75,415.00$ & $72,140.30$ & $71,761.80$ & $71,383.29$ & $75,273.46$ & $76,970.13$ & $79,443.99$ \\
\hline $\begin{array}{l}\text { Medium- } \\
\text { scale mills }\end{array}$ & $8,387.00$ & $9,225.70$ & $10,148.07$ & $10,836.00$ & $11,584.66$ & $12,357.44$ & $13,130.22$ & $13,903.00$ & $14,598.15$ & $15,345.05$ \\
\hline $\begin{array}{l}\text { Small-scale } \\
\text { and other } \\
\text { private } \\
\text { holdings }\end{array}$ & $250,888.00$ & $275,976.80$ & $303,572.32$ & $316,222.00$ & $342,012.51$ & $364,279.77$ & $386,547.04$ & $408,814.30$ & $429,255.02$ & $450,913.43$ \\
\hline
\end{tabular}

Source: MoFA (2017a) 
to meet the shortfall, with the large-scale plantations they depend on not able to produce enough to meet demand (Fold and Whitfield 2012).

In spite of the strategic importance of the oil palm industry, it has consistently underperformed for almost a century, and efforts by successive governments to promote it have only yielded weak results (see section six). This reflects the lacklustre performance of oil palm production in Africa. Between 1980 and 2011, Africa's share of the global commercial production of palm oil contracted from 27 per cent to 3 per cent, and the continent is unable to produce enough to meet internal demand (MASDAR 2011: 1.10). In 2008, production was only able to meet 55 per cent of the domestic demand. In 2010, West Africa produced less than 4 per cent of the global output. This poor performance is partially due to the dominance of smallholders, who rely on rudimentary processing technology (i.e. the semimechanised Kramer machine) and lack access to improved planting materials or finance. Smallholders plant the dura variety while the high-yielding improved tenera variety is planted by the estate plantations (Osei-Amponsah 2013). Within this regional picture, Ghana's performance is even poorer, accounting for 6 per cent of African CPO supply. By contrast, Nigeria produces 46 per cent and Cote d'Ivoire 16 per cent of the African output (MASDAR 2011).

Policy initiatives since the early 2000s have been focused on the opportunities arising from the regional and global demand for the commodity, although the immediate aim has been to reduce the import bill on palm oil (see Hypothesis Three in the Appendix). Although policies have yielded some modest results, growth in the sector has been sluggish and has lagged behind expansion in the global industry. A master plan study commissioned by MoFA in 2010 estimates that, if current production trends persist, CPO supply will only grow at a rate of 3 per cent per annum, meaning that in the 15-year period between 2010 and 2025, estimated production will only increase from $244,335 \mathrm{mt}$ to $382,000 \mathrm{mt}$. This growth in production will not be enough to absorb domestic demand, a situation which could shoot up the deficit from $32,000 \mathrm{mt}$ to $127,000 \mathrm{mt}$. The supply deficit for West Africa, which is also expected to grow at the same rate, is estimated at around 450,000mt by 2024 (MASDAR 2011).

This shows that oil palm has a potential to greatly contribute to the country's GDP. Additionally, the past few decades have witnessed an expanding demand for vegetable oils, with palm oil accounting for well over half of the global trade in edible oils. As Figure 3.1 shows, palm oil production grew from 1980-2010, more than doubling every decade. Between 1980 and 2008, global palm oil production grew from 4.5 million tonnes to 45.1 million tonnes. From an 11 per cent share in vegetable oil production in 1980, palm accounted for 34 per cent in 2010 (MASDAR: 1.20), outstripping the contribution of any other source of edible oil.

Figure 3.1 World production of vegetable oils, 1980-2008
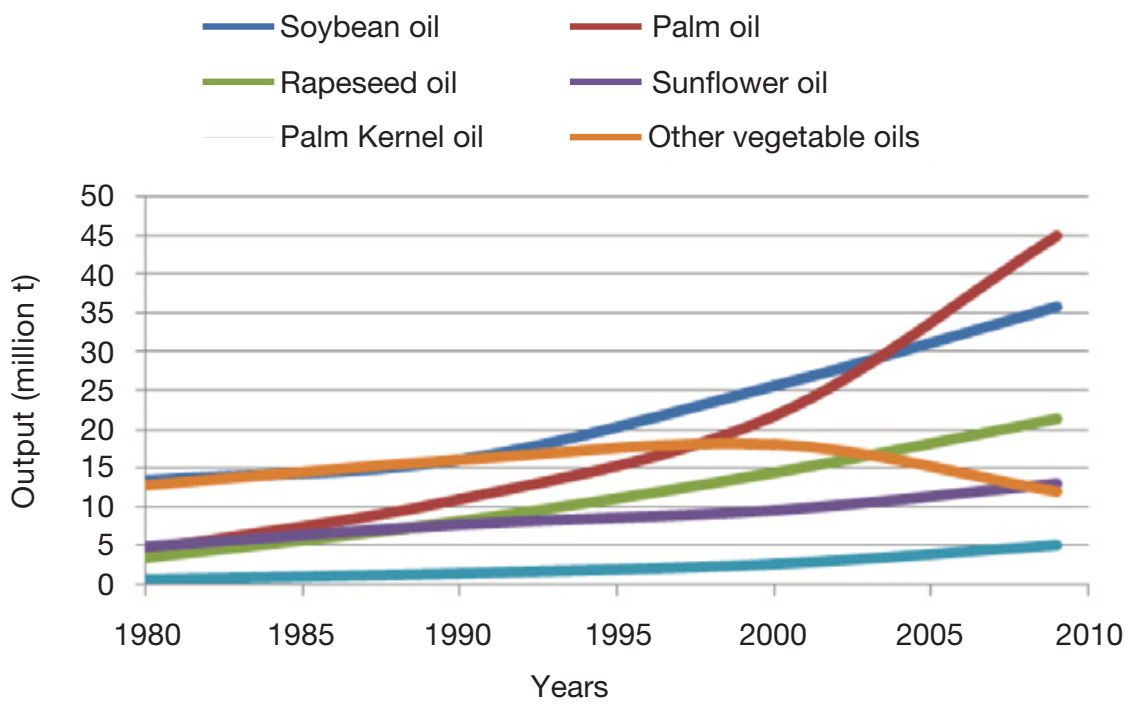

Source: MASDAR (2011) 
The structure of Ghana's oil palm industry has been shaped by it serving two distinct markets -domestic consumption and industrial processing - leading to two largely independent sub-sections within the value chain. The industrial processing sub-sector comprises of large- and medium-scale plantations, and processing mills. The estate plantations process $\mathrm{CPO}$ on site. This sub-sector is more productive because production takes place on a large scale, aided by superior and efficient technology. On the other hand, the home consumption sub-sector, dominated by independent smallholders, faces impediments like low-yielding varieties, fragmented landholdings, and rudimentary technology, factors that negatively affect its productivity and quality of output (Osei-Amponsah et al. 2014; Fold and Whitfield 2012: 14). Although analytically distinct, the two sub-sectors are not entirely separate. In reality, the industry is built on a rich diversity of co-existing production systems: ranging from the collection of palm nuts as a nontimber forest product (NTFP), to the domestication of oil palm through agroforestry and mixed crop production for local processing and local trade, to the establishment of industrial plantations and the export of palm oil as an internationally traded commodity (Khatun et al. 2020: 4).

The separate stages in the value chain include input supply, cultivation or production, processing, and marketing. Figure 4.1 shows the five core stages, as well as the outside actors who support, interact with, or are otherwise interested in the performance of the value chain.

\subsection{Stages along the chain}

\subsubsection{Input-provision}

The first stage concerns input provision. The necessary inputs include planting materials (sprouted seeds and seedlings), fertiliser, herbicides and insecticides, and

\section{Figure 4.1 The oil palm value chain}

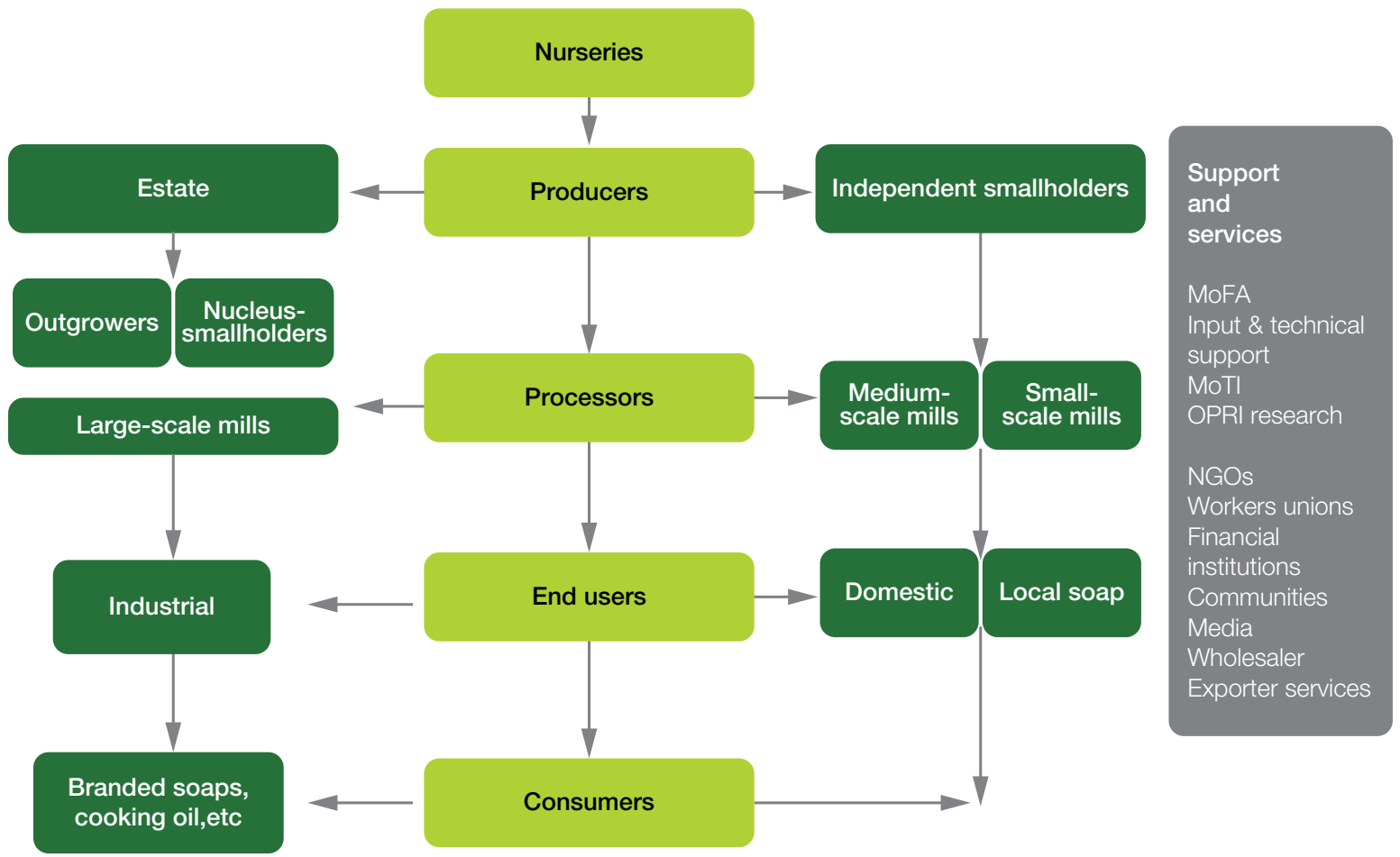

Source: Author's construct based on MoFA (2010) 
protective equipment like boots and masks. The Oil Palm Research Institute (OPRI) carries out research into oil palm development and supplies planting materials to growers. OPRI was originally established as a division of the Crop Research Institute of the Council for Scientific and Industrial Research (CSIR), but became an autonomous institute of CSIR in 1988. Since 1992, OPRI has taken on added responsibility for research into coconut, especially the Cape St. Paul's Wilt Disease (OPRI researchers, pers. comm. March 2020). The government, through MoFA, also provides technical and extension services to smallholder farmers (Ofosu-Budu and Sarpong 2013).

Other inputs, like fertiliser, can be purchased on the open market. In Ghana, fertiliser use is more prevalent on export or cash crops than on food crops (FAO 2005), even though fertiliser application across all crop sectors tend to be low, even in comparison to the African average (Banful 2009). The government introduced a fertiliser subsidy programme (FSP) in 2008 to encourage fertiliser use, but the programme has suffered many implementation challenges. These include inefficient distribution protocols, smuggling to neighbouring countries, and politically motivated targeting, whereby more fertiliser coupons were allocated to districts where the ruling government had performed poorly in the previous elections, in a bid to win more votes from these areas in subsequent elections (Banful 2011). Still, the FSP is only designed for food crop farmers, although an Oil Palm Development Association of Ghana (OPDAG) executive, who was interviewed for this study, believed the support should have been extended to oil palm producers.

\subsubsection{Cultivation}

There are three broad types of actors involved in production: 1) independent smallholders cultivating less than 10ha, 2) medium-scale plantations, and 3) large industrial plantations or estates. It should be noted that many of these actors can be found in both the artisanal and industrial segments of the value chain. Independent smallholders dominate production, accounting for about 80 per cent of all fresh fruit bunches (FFBs) produced (Ofosu-Budu and Sarpong 2013). Production takes place across six regions (Brong Ahafo, Ashanti, Eastern, Volta, Central, and Western), with Eastern accounting for the largest area under cultivation (336,000ha) (MASDAR 2011). Areas cultivated by estates has remained relatively unchanged, while those under independent smallholder cultivation has expanded substantially since the 1990s (see Figure 4.2).

Independent smallholders sell their fruit to either the industrial plantations or to medium-scale processors. A few engage in artisanal or small-scale processing for sale on local markets. Other smallholders are linked to the estates through nucleus and outgrower schemes. The nucleus schemes contractually bind the smallholder farmer to the estate on whose land they farm. Under these contracts, farmers receive planting materials, fertiliser, and other inputs from the estates as well as technical services on good agronomical practices. Cultivation may also be supervised by the estate. In turn, the smallholder farmer is obligated to sell to the estate (Ofosu-Budu and Ruml and Qaim 2020; Sarpong 2013). Outgrowers, on the other hand, cultivate adjacent land to the estate plantations. Like nucleus farmers, they also receive planting materials and other inputs from the estate on credit, which they repay in kind upon harvest on terms more favourable than what may be obtained from commercial banks. They remain under the contract until the loan has been fully repaid, after which they may continue to sell to the estates at an agreed price (OfosuBudu and Sarpong 2013).

\section{Figure 4.2 Area under estates and independent smallholdings}

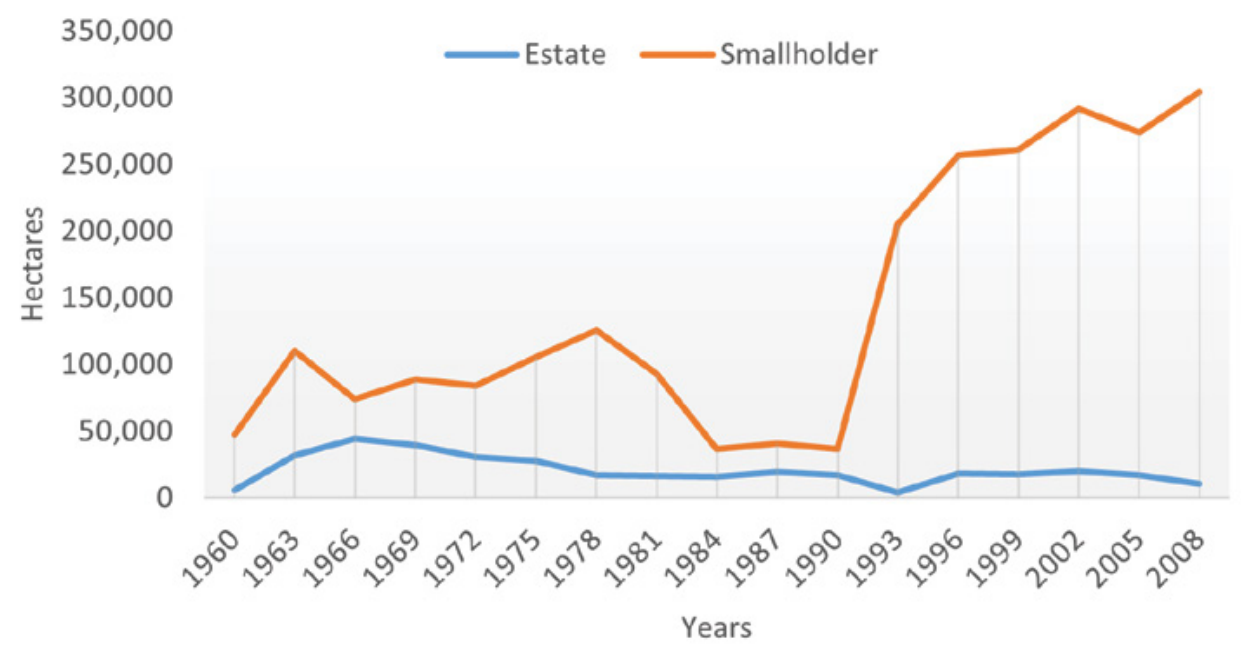

Source: Author's construct based on MASDAR (2011) 
Nucleus smallholders and outgrowers have access to superior inputs and technical services by due to their estate ties, but the dependence on the estates and the truncation of control over many aspects of production leads to resentment and a breakdown of trust (Ruml and Qaim 2020; Ofosu-Budu and Sarpong 2013). For instance, violations of the contract by the outgrower could legally empower the estate to take over the farm until the loan has been fully repaid (Ofosu-Budu and Sarpong 2013). Independent smallholders, on the hand, enjoy full production autonomy, although they rely largely on inferior planting materials, and are dependent on government extension officers, who tend to lack resources and are spread thinly across large areas. As a result, the productivity of estate farms is three times higher than that of smallholder farms (MASDAR 2011).

The large estates aim to reduce their reliance on smallholders by expanding their plantations. However, they are constrained by problems relating to access to land, which often end up with extensive litigation. Already, there are tensions between many estates and local communities over the lands on which the estates have been established, because of longstanding grievances arising from issues of compensation for the appropriated lands on which the estates were established (MASDAR 2011).

\subsubsection{Processing}

Palm oil processing serves both domestic consumption and industrial purposes. Actors involved in processing include large- and medium-scale mills, and smallscale processors. The home-consumption market is supplied by the small-scale or artisanal processors, who are mostly women (Ofosu-Budu and Sarpong 2013). Women who supplement farming with artisanal processing tend to be slightly better off than women who do not engage in similar off-farm economic activities (Dzanku et al. 2020). They buy FFBs from the open market, but some own their own oil palm farms. Artisanal processing is inefficient because it relies on rudimentary technology, a semi-mechanised processor - called Kramer - and the oil extraction rate is low.

The various stages of artisanal processing are labourintensive. For a typical working day, artisanal milling requires the labour of an average of 22 people, only a quarter of whom are men. Their jobs include transferring the fruits from trucks to shed, de-fruiting, removal of fruits, loading into boiler and boiling, moving the boiled fruit to the Kramer machine, pounding and squeezing, carrying to the frying pan, and frying the oil (Ofosu-Budu and Sarpong 2013: 364). The processed oil is supplied to market women, for onward transport to markets across Ghana, and to Togo and Nigeria.
The quality of CPO produced by the artisanal millers reflects their overall technological limitations. Moreover, processing practices, such as long storage of fruits before boiling, using tyres as fuel during boiling, and skipping the process of clarification of the oil in order to cut costs, negatively affects the quality of CPO (OseiAmponsah et al. 2012). Furthermore, CPO produced by artisanal millers is high in free fatty acids (FFA), making it uncompetitive in the high-paying markets (Osei-Amponsah et al. 2014). Estimates of net revenue of artisanal processing by Ofosu-Budu and Sarpong (2013: 370-1) show that processors derive more benefit by scaling-up production. They find that on average, in communities processing 30t of FFB per week in 2011, processors made a margin of $\mathrm{GH} \$ 23$, while those processing 10t a week made a GH\$20 profit. Those producing only 1t a week ran at a loss. Women, who tend to lack access to off-farm income that is so crucial to acquiring improved technology for artisanal processing, reap only a moderate profit from milling (Dzanku et al. 2020).

Medium-scale mills were established in the 1970s and early 1980s and are predominantly privately-owned by Ghanaians. A few of these mills have their own oil palm plantations of between 120 and 430ha. Thus, they rely heavily on supplies from independent smallholder farmers (Fold and Whitfield 2012). In general, their rate of extraction is less efficient than the estates, who use industrial-level equipment for extraction.

The large-scale mills are owned by the estate plantations, namely Ghana Oil Palm Development Corporation (GOPDC), Benso Oil Palm Plantation (BOPP), Twifo Oil Palm Plantation (TOPP), Ameen Sangari, Norpalm Ghana Limited, and Juaben Oil Mills. In 2010, the total combined annual output of the main processors was 432,844mt FFB. Just under a quarter of this was produced by GOPDC, with Ameen Sangari second with 92,000mt. At 29,000mt, Juaben processed the least amount of FFBs (MASDAR 2011: 2.7).

Ameen Sangari, the only private mill, is also the oldest, having started in 1919 in Cape Coast as a soap manufacturer. It started producing CPO and palm kernel oil (PKO) as raw materials for soap manufacturing, although as of 2010, it was sourcing over 88 per cent of FFB from independent smallholders. After many years of commercial struggles, in March 2020, it was permanently closed after staff staged a protest over unpaid salaries and redundancy packages (Amarteifio 2020).

By contrast, most of the estate mills started as state initiatives or as partnerships between the state and foreign investors. GOPDC was founded in 1975, as part of the government's attempt to diversify agricultural 
production, while BOPP and TOPP were established in 1976 and 1977 respectively as joint ventures between the government and investors. After structural adjustment, the state-owned estates were privatised. In 1995, Siat Group, of Belgium, acquired 60 per cent of GOPDC, while Unilever acquired 40 per cent of government shares in TOPP. Meanwhile, National Oil Palm Limited was acquired by Norpalm ASA, which established Norpalm Ghana Limited. BOPP is currently owned by Wilmar Africa (MASDAR 2011).

CPO and PKO can be refined into various palm oils and fats, and is used in the food, detergent, cosmetic, and chemical industries. In the food industry, it is used as an ingredient for biscuits, chocolate, cooking oil, ice cream, margarine, and mayonnaise. The kernel can be processed into meals for animal feed. Palm oil has other advanced industrial applications, such as oleo chemicals, pulp and paper, and butter fats, which Ghana has not yet developed the processing capacity for (Fold and Whitfield 2012; MASDAR 2011).

Currently, Unilever processes soap and cooking oil called Frytol, and GOPDC produces King Vegetable Oil. GOPDC has a refinery/fractionation plant, a biomethanation plant, and produces palm kernel cake pellets. Companies in Ghana who also have refinery and fractionation facilities include Unilever, PZ Cussons, and GOPDC (MASDAR 2011). These companies produce palm oil that meets international standards. Unilever is the largest buyer of CPO from the medium- and largescale mills for downstream processing of consumer products. However, Ghana does not produce enough $\mathrm{CPO}$ to meet industrial demand, hence, the country continues to be a net importer of CPO. Nevertheless, small quantities of Ghanaian CPO are exported to niche ethnic or organic markets in the US and Europe (executive of Artisanal Palm Oil, pers. comm. March 2020; Fold and Whitfield 2012).

\subsection{Other actors}

Transportation service providers, and agents or aggregators, perform integrative functions along the chain. Aggregators connect smallholder farmers to the large estates. Some aggregators are directly employed by the estates but many operate on their own account, deriving a small profit from the difference between the price they offer to farmers and the amount the mills pay for their fruits. Transportation is a crucial support service in the value chain. Oil palm cannot be stored for long because it starts losing moisture soon after harvesting, and the harvest must be transported for downstream-processing, or to home-consumption markets, as soon as possible. This is often hampered by the poor state of the roads in communities producing the crop, and negatively affects farmers' income and generally impedes efforts at improving productivity (Heerink, Atsma and Fosu 1997).

Policymakers are an influential set of actors who have enduring interests in the performance of the industry because of its contribution to the national economy. By setting the broad policy framework within which players along the value chain pursue their goals, policymakers are able to influence the performance of different actors in the value chain by shaping the distribution of incentives (such as subsidised seedlings) within the value chain. Therefore, they are able to influence which actors win, or lose, along the value chain.

The industry-wide association also plays a key role in improving the productivity of the value chain. The first such association, the Ghana Oil Palm Development Association (GOPDA), was inaugurated in 1985. In addition to promoting cooperation and information exchange among the dominant players, it also functioned as a mouth-piece for the actors in the value chain, and negotiated with government on behalf of actors in the value chain. In the early 1990s, it succeeded in influencing government's decision to increase tariffs on imported vegetable oil and soaps, and also established a pricing formula, which priced FFBs at 10 per cent of factory gate price of CPO. However, the association started declining from the early 2000s, coinciding with the privatisation of major state-owned estates such as GOPDC and National Oil Palm Plantation Limited (NOPL) (MASDAR 2011). The large estates were the core of this association, but believing that the price-setting function of the GOPDA harmed their own interests, they felt constrained by the association (OPDAG Secretary pers. comm. March 2020). With support from Busac Fund and Solidaridad, the association was revived in 2015 as the Oil Palm Development Association of Ghana (OPDAG) which pursued many of the same goals as GOPDA (executive of OPDAG, and officials of Solidaridad and Busac Fund pers. comm. March 2020). However, an important new objective of the association is ensuring environmental sustainability, as prescribed in the Roundtable on Sustainable Palm Oil (RSPO) (OPDAG no date).

The international development community has also become directly or indirectly involved in the industry (see Hypothesis Five in the Appendix). These include the Commonwealth Development Corporation, European Union, World Bank, International Finance Corporation, African Development Bank, Nederlandse Financierings-Maatschappij voor Ontwikkelingslanden N.V., and Agence Française de Développement (AFD). AFD has a longstanding interest in rubber and oil palm in Ghana. In 1995, together with the World Bank, AFD provided a credit facility to the Ghanaian government to finance tree crops like oil palm and rubber, under 
the Programme for the Promotion of Perennial Crops (PPPC), and has since supported oil palm and rubber outgrower schemes (Ambassade de France au Ghana 2015). In 2006, AFD and Kreditanstalt für Wiederaufbau signed another credit facility with the government for the PPPC programme to run from 2006 to 2013 (MoFA no date). However, an AFD official interviewed for this study complained that the PPPC was not used, even though they spent a lot of money developing it. For instance, a tree crop authority, similar to Tree Crop Development Authority (TCDA), was supposed to have been set up under the PPPC, but this did not happen. AFD currently has no ongoing oil palm project (interview AFD official on March 2020).

The Embassy of the Netherlands in Ghana has been involved in the oil palm value chain since 2012, providing support under the Sustainable West African Oil Palm Programme (SWAPP). The embassy is mainly interested in promoting private sector participation in the value chain and encouraging sustainable production. Currently, they are supporting the implementation of PERD by training district agricultural development officers in nursery management and best practices. CSOs active in the sector (such as Solidaridad), and other development agencies like AFD and KfW (official of the Embassy of the Netherlands pers. comm. March 2020).

Financial institutions, both domestic and donorrelated, have also continued to play influential roles in the workings of the value chain. Funding from the government and external sources can be accessed through the National Investment Bank (NIB) and the Agricultural Development Bank (ADB). Domestic sources of financial support for the industry have come from Ecobank Ghana, Barclays Bank, Merchant Bank, and the Social Security and National Insurance Trust (MASDAR 2011).

As discussed above, civil society or non-governmental organisations (CSOs and NGOS) have also been active in the industry. These have usually worked closely with donor agencies to channel resources to actors within the industry, or to organise training. The Embassy of the Netherlands, for instance, supports OPDAG indirectly through Solidaridad (official of Embassy of the Netherlands pers. comm. March 2020). Since 2012, Solidaridad has been involved in the value chain under the SWAPP, with funding from the Embassy of the Netherlands. They provide training to smallholders on best practices under the Roundtable for Sustainable Palm Oil (RSPO) (interviews with officials of the Embassy of the Netherlands and of Solidaridad, March 2020). Proforest, another non-profit organisation, also supports sustainable production of agricultural commodities and works closely with the government, companies, and other CSOs involved in the value chain on the national interpretation of the RSPO (officials of Proforest pers. comm. March 2020). In line with their concern over environmental sustainability, they assist smallholders and artisanal millers to intensify production, in order to curb the exploitation of forest lands for expansion. They were instrumental in the revival of the industry association, the Oil Palm Development Association of Ghana (OPDAG), and worked closely with OPDAG and other stakeholders for the passing of the bill setting up TCDA (interview with official of Solidaridad, March 2020).

\subsection{Challenges}

Due to the segmented nature of the value chain, smallholders and estates must confront distinctive sets of challenges. As noted above, smallholders lack access to improved planting materials and other inputs like fertilisers, a situation which severely constrains their productivity. This, in turn, ultimately lowers the productivity of the entire value chain, since smallholders account for such a large proportion of production. Policies for the past two decades have been focused on improving the productivity of smallholders. However, to date, these policies have failed to deliver the expected benefits. In the case of the President's Special Initiative on Oil Palm (PSIOil Palm), the failure resulted from poor coordination between the various government agencies involved in the implementation of the programme, as well as struggles between competing factions of the ruling party that further reduced the administrative coherence and effectiveness of the programme (Asante 2012).

Access to farmland for smallholder farmers is becoming an increasingly complicated issue. Tenure insecurities arising from ownership disputes is an established problem confronting smallholders. However, since the deregulations and market liberalisation that followed in the wake of structural adjustment in the 1980s, largescale land acquisitions facilitated by local chiefs has intensified land dispossession and tenure insecurities across the country, and sub-Saharan Africa (Tsikata and Yaro 2013).

The industrial segment of the value chain faces its own sets of challenges. The lack of litigation-free land poses a serious problem to any attempt to expand production. According to the MoFA-commissioned masterplan, up to 50,000ha parcels of lands 'are potentially available' in the Western and Central Regions for the establishment or expansion of plantations. However, the intricacies of land tenure and access arrangements, with long and drawn-out litigations, often present investors with substantial challenges (Amanor, Yaro and Teye 2020; Yaro, Teye and Torvikey 2018; MASDAR 2011). 
For an outsider, the landholding arrangement can seem confusing, as described by Fold and Whitfield:

In short, land cannot be easily bought and sold. Acquiring large pieces of land involves a long process of negotiations with landowners, chiefs, people on the land, as well as compensation for the land, people on the land and structures on the land. And even after compensation is paid, new claims might arise (Whitfield and Fold 2012: 12).

Even for the well-established estates, the land question is not fully settled. Since most of these began as stateowned enterprises, on land forcefully expropriated by the state, decades-long litigations and compensation demands are common, even after the estates have been transferred to private hands. As a conciliatory measure, the estates have had to devise schemes to assuage the resentment of communities who were affected by government expropriation. For instance, GOPDC has a smallholder scheme that incorporates those who would, have otherwise, been displaced (Fold and Whitfield 2012).

The industrial-use sector often faces unstable or unreliable supply of FFBs, because they have to compete with the market for home-consumption. To meet the shortfall, the estates enter into different arrangements with smallholders to supply them with FFBs. Nucleus smallholder and outgrower schemes are examples of these arrangements. But contract violations, including side-selling, is rampant among smallholders. The situation is so bad that some estates, like BOPP, avoid contracts altogether, even to farmers under their outgrower schemes, because such contracts are no guarantee against side-selling (BOPP manager pers. comm. March 2019). On their part, smallholders greatly distrust contracts, even though studies have shown that farmers under contract are better off than their counterparts cultivating independently (Ruml and Qaim 2020).

Attention is now being increasingly directed at the environmental impact of oil palm production. Globally, expansion in oil palm cultivation has been linked to growing deforestation, as virgin forests are cut down to make way for plantation development, in the process contributing to the destruction of rainforests and loss of biodiversity. In addition, there are hazardous effects on humans, as runoff from agro-chemicals and effluents from industrial mills drain into water bodies which serve as sources of drinking water (Opoku and Asante 2008). NGOs like Solidaridad and Proforest, and development partners like AFD and the Embassy of the Netherlands, have been helping producers to meet international sustainability standards as enshrined in the RSPO (officials of AFD, the Embassy of the Netherlands, Solidaridad, and Proforest pers. comm. March 2020).
Finally, the wider policy context presents problems which affect the performance of the value chain. Although government policy since the early 2000s has tended to be supportive of agricultural development, and the oil palm sector in particular, the politics of policymaking has often limited the transformative potential of such policies. For instance, former president, John Kufuor, established the President's Special Initiatives in August 2001 shortly after ascending to power. However, despite PSI-Oil Palm being instituted in full view of the presidency and its constitutionally-guaranteed powers, it ultimately failed. This is partly because of power struggles between government agencies and ruling party factions that hampered its implementation. The programme directed most of its benefits to independent smallholders, even though the large estates were meant to play a central role in supporting the programme. Tensions about the programme emerged during a consultation workshop between government and stakeholders in 2004, shortly before the programme was rolled out, leading to the eventual withdrawal of the estates from the programme (Asante 2012). The holding power of the estates was demonstrated by the fact that not only did they survive without the support of the PSI-Oil Palm programme, but that their withdrawal eventually led to the termination of the programme.

Actors in the value chain have long called for government protection from cheap imports of vegetable oil. In recent times, governments' reduction of the benchmark value of imported edible oils have generated serious concern among actors in the value chain. Local producers, both artisanal and industrial, complained that the situation made locally-produced vegetable oils uncompetitive, and that failure to reverse the policy could trigger massive unemployment. On this issue, their interests are at odds with the Ghana Union of Traders' Associations, an extremely influential group for mostly urban-based traders. The large size of Ghana's informal economy makes the association powerful actor in local market regulation and import policies. Consequently, the government is reluctant to introduce policies likely to antagonise them because of the negative implications towards election results that could happen by upsetting a potential voting bloc (manager of GOPDC, official of the Embassy of the Netherlands, and executives of Artisanal Palm Oil and OPDAG pers. comm. March 2020; Bentil 2019). A series of errors occurred in May 2020 when the government had to quickly reverse an announced exemption of vegetable oils from benchmark reduction, even after OPDAG had publicly praised the government on the move (B\&FT 2020). However, this information was surreptitiously communicated to OPDAG to avoid embarrassment to the government (executives Artisanal Palm Oil, OPDAG pers. comm. May 2020). 
Inclusive value chain analysis is motivated by inclusive ideals (i.e. poverty reduction, empowerment, and reducing inequality), but it is often limited by a tendency to identify all non-plantation farmers in a homogenous 'smallholder' or 'peasant' category. This is an important conceptual limitation, because failure to acknowledge the heterogeneity among smallholders could result in a situation of 'adverse incorporation' (Hickey and Du Toit 2013). This would affect the most disadvantaged actors in the value chain, whose fortunes remain either unchanged, or may actually decline, because benefits tend to be unequally distributed in favour of those who already possess more power or resources (Manley and Van Leynseele 2019).

As explained above, Ghana's oil palm industry is largely split into two branches, with the main lines of social difference defined by peasant production or production for the global market (industrial processing). Beyond this broad categorisation, smallholder farmers differ on the bases of their mode of market participation and livelihood outcomes. Manley and Van Leynseele (2019) identifies four types of smallholders based on mode of market participation, as expressed in their contractual relations and participation in the estate/global or artisanal (or Kramer) markets. Among contract farmers, they distinguish between 'faithful' contract farmers, who possess enough prior assets, and for whom contractual attachment to the estates is a better alternative to participating in the 'Kramer' market. They also describe the 'unfaithful' contract farmers, who only attach themselves to the estates out of necessity (to acquire inputs or access to land), and who are often dissatisfied about their contract terms. Between these two types of contract farmers, the 'faithful' farmers are better off in terms of income and wellbeing (see also Dzanku et al. 2020). By contrast, independent farmers can be categorised into 'free choice' and 'marginalised' farmers. In general, independent farmers tend to earn much less than both categories of contract farmers, but marginalised farmers are the worst-off category. For instance, their off-farm activities are geared more towards meeting livelihood needs than on on-farm investments.

These social differences overlap with, and sometimes complicate, existing social inequalities in access to resources and power. For instance, because women tend to lack secure access to land, they are less likely than similarly-endowed men to enter into contractual arrangements with the estates (Dzanku et al. 2020), which is premised on the assumption of tenure security. At the household level, control of oil palm farms tends to be vested in males. The division of labour on farms also tends to be heavily gendered, with men performing tasks like land preparation, planting, weeding, pruning and harvesting while women tend to assist with nursery management, handle rodent control, and carry harvested fruits (Ofosu-Budu and Sarpong 2013: 364). When labour is sourced from outside the family, men benefit from the unequal remuneration of gendered tasks involved in cultivating and harvesting the crop. Further, artisanal processing is female-dominated, although the machinery tends to be owned by men (Ofosu-Budu and Sarpong 2013).

Growing land scarcity, partly fueled by largescale agricultural land deals following the entry of multinational capital in the sector after structural adjustment (Yaro, Teye and Torvikey 2018: 60) has exacerbated the problem. This is because it has further entrenched existing inequalities in the ruthless competition for access to available land in which "the powerful displace the weak". This process is underway across different crop value chains, as observed by Amanor and colleagues (Amanor, Yaro and Teye 2020: 25): "the youth are increasingly dependent upon elders for land, while elders compete among themselves for control of land and family labour. Both youth and women/wives are no longer guaranteed easy access to land". A recent study in oil palm growing villages in the Ashanti and Central Regions report that access to land is influenced by a combination of one's personal networks, local political connections, and gender (Khatun et al. 2020).

Finally, these differences also structure how benefits and costs of global initiatives such as the RSPO, are unequally distributed among value chain actors. Khatun et al. (2020: 2) have demonstrated that the "universalising logics of certification" risks worsen the livelihoods of the most vulnerable actors in the value chain - women farmers, millers, and traders - who may be have to bear the brunt of compliance even 
though they do not directly participate in the global market (see also Castellanos-Navarrete and Jansen 2018). And with a large unmet local and sub-regional demand, many smallholders do not seem keen to acquire RSPO certification. According to a smallholder farmers' representative, they only participate in NGOorganised sustainability workshops in order to collect the Wellington boots and other goods distributed at such events (interview with executive of Artisanal Palm Oil, May 2020). 


\section{POLICYMAKING WITH RESPECT TO THE CHAIN}

\subsection{From early independence to period of crisis}

By independence in 1957, the old oil palm belt had disappeared, and Ghana was a net importer of palm oil. The newly independent government of Kwame Nkrumah embarked on an aggressive agenda to revive the oil palm economy as part of a broader strategy of import substitution. Because palm oil constituted an important ingredient in dishes in southern Ghana, the large volumes of palm and other oil imports imposed a heavy constraint on the economy (Fold and Whitfield 2012; Gyasi 1992). In 1964, OPRI was established to, among other things, conduct scientific research into oil palm development and to supply improved seedlings to cultivators.

Post-independence governments differed from their colonial predecessors by the careful attention they paid to oil palm and their direct involvement in it. Efforts to promote the oil palm industry were streamlined into broader national development plans and strategy documents by post-independence governments. These included the five-year development plan (19591964), the seven-year plan (1964-70), the two-year plan (1969-71), the five-year plan (1975-1980), the Structural Adjustment Programme (1982-1992), Vision 2020, and the Ghana Poverty Reduction Strategy I and II. These efforts have been geared towards expanding production and processing capacities, poverty reduction and employment creation, reducing the overreliance on cocoa, gold, and timber, and economic transformation by attracting large capital investment into the oil palm sector (MASDAR 2011: 1.2).

The actual implementation of oil palm industryspecific policies were shaped by ideological, strategic, and partisan or factional considerations. The statist approach of the Nkrumah government stood out starkly against the hands-off approach adopted by the colonial regime for most of its tenure. And while the colonial regime was mainly interested in enhancing the export revenue generated by the industry, Nkrumah's government followed an import substitution strategy aimed at satisfying domestic household consumption as well as industrial needs. In pursuit of these goals, the State Farms Corporation and independent producers were supported to increase the area under cultivation. In 1962, the State Farms owned only one of five small mills, but by 1987, this has increased to four stateoperated estates in Prestea, Sese, Kwamoso, and Asesewa (MASDAR 2011: 1.3).

After Nkrumah's overthrow in 1966, economic policy alternated between protectionism and outward orientation. The market-oriented government of Kofi Busia (1969-1972) kept the state-owned enterprises formed under the Nkrumah government, but policy orientation shifted from import substitution to production for export. During this period, the State Farms Corporation established new plantations and expanded processing capacity. However, the Busia government was short-lived, and Ghana continued to import vegetable oil to meet the domestic shortfall until his successor, General Acheampong, sought to reverse the situation with the Five-Year Development Plan (1975-1980), which resulted in the establishment of three large estates, namely Benso Oil Palm Plantations Limited (BOPP), Ghana Oil Palm Development Corporation (GOPDC), and TOPP (MASDAR 2011). This also involved a reversal from the market orientation of the Busia government.

A combination of political and economic crises in the late 1970s resulted in the dramatic rise of a young Flt Lt Jerry John Rawlings, who by 1981 had successfully carried out two coups d'etat. Although initially espousing a strong marxist ideology, the extreme economic crises of the early 1980s forced him to quickly reverse course and adopt economic recovery and structural adjustment programme (ERP and SAP) policies (Teye and Torvikey 2018; Boafo-Arthur 1999). The oil palm industry received a boost under the push towards economic liberalisation policies in the 1980s. The decade saw the consolidation of the models implemented in the previous decades, the rehabilitation and expansion of existing plantations by the State Farms Corporations, including the incorporation of estates at Pretsea/Sese as the National Oil Palm Limited (NOPL) as a commercial entity (MASDAR 2011). The 1990s witnessed an aggressive drive to divest government interests in oil palm production, so that by 2007, government had privatised nearly all the State Farms plantations, including GOPDC, BOPP, 
TOPP, and NOPL (Appiah-Kubi 2001). In 2007, Appiah Menkah Complex Limited acquired the last oil palm asset of the State Farms Corporations (MASDAR 2011).

In spite of these reforms, the industry was still unable to satisfy domestic demand by the turn of the twentyfirst century. In 2003, the government of John Kufuor initiated a grand support programme, dubbed the PSIOil Palm, under the direct control of the presidency in a bid to expand production. However, the overall result was disappointing, and the programme terminated before the end of his tenure as a result of a combination of factors, including funding constraints, and lack of administrative coordination between government agencies responsible for implementation (Asante 2012; Fold and Whitfield 2012).

A key insight from this brief historical account is that, the active interest of post-independence governments in promoting the oil palm industry notwithstanding, the broad policy environment was marked by political instability. One major source of this instability was the numerous military interventions that the country experienced. Between 1966, when the Nkrumah government was overthrown, and 1980, when the Hilla Limann government was toppled, the military had overthrown five governments, three of them democratically elected. And it was not until 2001 that the country experienced its first transition of power from one democratically elected government to another. These frequent abrupt changes of government affected the implementation of broad development plans, including specific policies targeting the oil palm sector. For instance, after the 1966 coup, the sevenyear development plan of Nkrumah was abandoned, as was the two-year plan of Busia when he was overthrown (MASDAR 2011).

In addition to political instability, policy implementation was also hampered by weakened state capacity resulting from factional politics and the use of state agencies as a vehicle to reward political supporters. The resulting corruption and mismanagement undermined efforts to promote the value chain (Gyasi 1992). Together with the ever-present problem of inadequate financial resources, which grew worse in the 1970s, these factors effectively frustrated Ghana's efforts to produce enough palm oil to meet the domestic demand. Thus, the shift towards privatisation in the industry was embraced by stakeholders, with the expectation that by ceding space to the private sector, the industry would finally enter a phase of rapid growth.

\subsection{After adjustment: the politics of a new era?}

Following the economic crisis of the late 1970s and early 1980s, Ghana was forced to undergo thoroughgoing economic reforms as a precondition for aid. The structural reforms of the 1980s championed by the World Bank and the International Monetary Fund (IMF) proved successful; in fact, surprisingly so, according to scholars like Boafo-Arthur (1999), given that the country simultaneously embarked on a democratic transition while implementing draconian structural adjustment policies. However, the inauguration of the Fourth Republic in January 1993 radically shortened the time-horizon of the Rawlings regime (Whitfield 2011a) and increased the number of actors vying for rent by opening up the political arena to erstwhile excluded actors into the policy process (Resnick 2016; Boafo-Arthur 1999). Although the democratic transition was widely expected to usher in a new era of politics and development, it has widely failed to meet expectations. Analysts argue that it has instead reinforced patronage politics under the pressure of electoral calculations. The result is a political settlement which scholars describe as 'competitive clientelism', in which elections are meaningful because they routinely lead to peaceful transitions, but have little impact on the deeply entrenched system of patronage, extractive corruption, or the politics of impunity (Asante and Khisa 2019; Appiah and Abdulai 2017; Whitfield 2011a).

Even though democratisation increased the range of actors in the political arena, they were not all equally successful in influencing policy. In fact, a paradoxical situation emerged: even though the logic of economic liberalisation mandated an active role of the private sector in the economy, government-business relations remained frosty throughout the Rawling era spanning the Provisional National Defence Council (PNDC) (1981-1992) and the National Democratic Congress (NDC) (1993-2000) governments. This hostility derived from the strongly Marxist bent of the early PNDC regime, but the government also harboured suspicions that private wealth can be used to finance its opponents (Whitfield 2011a; Tangri 1992). On the other hand, the imperative to win elections strengthened both horizontal factions of political parties - who can mobilise monetary and other resources to sponsor electoral campaigns - and lower level factions (referred to as foot soldiers or vigilantes in Ghanaian political colloquialism) - who perform a variety of street-level tasks including canvassing of votes and protection against harassment or intimidation from political opponents, or inflicting this themselves (Khan 2005). This situation where genuinely competitive democratic politics exacerbates, rather than reduces, the use of patronage as an instrument of power-preservation is referred to as 'competitive clientelism'. The pressures of this competitive-clientelist logic was so strong that in spite of the New Patriotic Party's (NPP) strong marketleaning ideology, organised business interests did not 
fare any better under the Kufuor government (20012008) than they did under Rawlings (Whitfield 2011b).

However, external actors, including the World Bank, IMF, and other development partners have continued to be important stakeholders in the policymaking process owing to their financial and technical support for government policies and programmes (Teye and Torvikey 2018). Accordingly, agricultural policies since 2001 have borne the fingerprint of international development agencies and are designed to coincide with the prevailing development narratives. In response to the priorities of programmes overseen by donors such as the Foreign, Commonwealth and Development Office, International Fund for Agricultural Development, GIZ, the World Bank, and United States Agency for International Development, agricultural policies have been designed to address issues of food security, rural poverty, provision of infrastructure, as well as input subsidy and marketing support. The ideological basis for these programmes strongly favoured a public-private partnerships strategy. The fact that it coincided with electoral calculation partly explains why they have remained constant elements of the agricultural policies of both NPP and NDC governments (Teye and Torvikey 2018: 18-19).

Thus, in spite of the aggressive reduction of the role of the state in the economy in the 1980s, the 1990s witnessed new forms of state interventionism involving massive capital investment. Many of these policies had explicit poverty reduction and rural development goals. For instance, the goals of the Medium Term Agricultural Development Programme (1991-2000) included crop productivity as well as developing marketing systems and rural infrastructural development. From 2001, policies have sought to, among other things, supply raw materials for domestic industrialisation or promote commodity chains of selected export crops (FASDEP I and || 2002; Tree Crop Strategy 2012), supply inputs like improved seeds or fertilisers (National Fertiliser and Seed Policies 2010), promote food security and poverty reduction (FASDEP I and II; Medium Term Agricultural Sector Investment Plan [METASIP I and II] 2011-2015), and encouraging private sector participation (GCAP 2012; Teye and Torvikey 2018: 19-20).

The actual implementation of these policies have often been mired in the logic of electoral calculations. For instance, the fertiliser subsidy programme introduced in 2008, in response to the global food and energy price hikes, was supposed to be limited (targeting beneficiaries using vouchers) and time-limited (Banful 2009). However, not only did the programme continue beyond its intended end date, but it was expanded in scope from a targeted to a universal subsidy programme because of the fear that ending it would hurt the government's electoral polls. It is a testament to the force of the electoral imperative that the programme has continued across the tenure of four presidents (John Kufuor, John Atta Mills, John Mahama, Nana Akufo Addo). Moreover, a study by the International Food Policy Research Institute discovered that under the voucher system, allocation was manipulated to favour districts where the ruling party had lost in the previous elections (Banful 2011), thus, turning the policy into a patronage tool.

\subsection{Oil pallm specific policies since 2000}

Sector specific policies have aimed to boost output through both extensification (by increasing the area under production) and intensification (by increasing the yield per ha) of cultivation. Early policy initiatives were geared towards easing the constraints on the country's foreign exchange reserves by reducing imports bill (see Hypothesis Three in the Appendix), as well as capturing the Economic Community of West African States market, where unmet demand in 2004 was estimated at 850,000mt (cited in Opoku and Asante 2008, Toledano et al. 2004). Under the Food and Agricultural Sector Development Policy programme, the government sought to promote the cultivation of improved seeds and to expand the processing capacity of artisanal mills.

In 2003, when the PSI-Oil Palm was launched, there was optimism about its potential for success given that it was under the direct oversight of the most powerful political office. The aim of the PSI-Oil Palm was to expand production enough to meet the domestic and sub-regional demand. To meet this objective, the government was to support the OPRI to expand its capacity for producing planting materials. To expand the area under cultivation, groups of farmers were to be organised to cultivate 5000ha plantations with a 20t FFB/h mill established on-site with the help of the private sector. The ultimate aim of the initiative was to bring 200,000ha under cultivation (Adjei-Nsiah, SakyiDawson and Kuyper 2012; Opoku and Asante 2008: 18).

As part of the initiative, the government devised a corporate village enterprise (COVE) model under which smallholders would control majority shares in processing mills linked to the PSI-Oil Palm farms but whose day-to-day administration was under professional management. The PSI-Oil Palm was able to add about 20,000ha of oil palm to the national stock (MASDAR 2011), but fell far short of its intended 200,000ha. This model did not take off because of the heavy smallholder leaning of the PSI, and the dissatisfaction of private sector actors over the 
design and emphasis of the initiative. Instead of the COVE model, estates had wanted the PSI-Oil Palm to strengthen the connection between independent smallholders and company mills (Asante 2012). This tension was inevitable because the bifurcated nature of the value chain made it almost impossible to satisfy both sectors using the same policy. This was further exacerbated by the fact the policy was meant to satisfy two incompatible goals:

1. reducing the import bill by boosting local production of edible oils, a policy which required that government prioritises the industrial processing stream of the value chain; and

2. reducing rural poverty by boosting smallholder production, which the COVE model sought to attain by empowering smallholders to produce and process their fruits on a large-scale.

In the end, the estates withdrew from the programme over these disagreements. The fact that the PSI-Oil
Palm eventually collapsed without the support of the estates (Asante 2012) demonstrates the holding power that these estates wield in terms of policies affecting how the chain operates.

The PSI-Oil Palm was also severely affected by interagency coordination issues and factional struggles within the ruling NPP party. The identification of the programme with Alan Kyeremanteng and the Ministry of Trade and Industry made other agencies, in particular MoFA, hesitate to give it the support it needed. Kyeremanteng, was widely considered "the political power behind the PSls programme" (Asante 2012: 25). After he was made Minister for Trade and Industry, the programme was moved from the direct supervision of the president's Chief of Staff to his ministry. It then briefly came under the supervision of Kwamena Bartels, the minister for Private Sector Development, when it was moved to his ministry. A cabinet reshuffled later reassigned Kyeremanteng to the ministry for Private Sector Development, which

Table 6.1 Summary of Ghana's political and economic regimes

\begin{tabular}{|c|c|c|c|}
\hline Date & Government & Type & Economic/political stance \\
\hline 1957-1966 & $\begin{array}{l}\text { Dr K. Nkrumah, Convention } \\
\text { People's Party (CPP) }\end{array}$ & Civilian & $\begin{array}{l}\text { (Starting in 1960) Socialist; inward-looking; } \\
\text { protectionist; high levels of public spending and } \\
\text { establishment of state owned enterprises. }\end{array}$ \\
\hline 1966-1967 & $\begin{array}{l}\text { Col. A. Afrifa/ Gen. E. Kotoka, } \\
\text { National Liberation Council (NLC) }\end{array}$ & Military & $\begin{array}{l}\text { Renounced socialist orientation; austere, tentative } \\
\text { steps towards liberalisation. }\end{array}$ \\
\hline 1969-1972 & Dr. K. A. Busia, Progress Party (PP) & Civilian & $\begin{array}{l}\text { Market oriented; stronger moves towards } \\
\text { liberalisation; attempted large devaluation. }\end{array}$ \\
\hline 1972-1977 & $\begin{array}{l}\text { Gen. I. Acheampong, National } \\
\text { Redemption Council (NRC) }\end{array}$ & Military & $\begin{array}{l}\text { Inward-looking; protectionist; reversal of the Busia } \\
\text { devaluate. }\end{array}$ \\
\hline 1975-1978 & $\begin{array}{l}\text { Gen. I. Acheampong, Supreme } \\
\text { Military Council I (SMC I) }\end{array}$ & Military & Inward-looking; protectionist. \\
\hline 1978-1979 & $\begin{array}{l}\text { Gen. F.W.K. Akuffo, Supreme } \\
\text { Military Council II (SMC II) }\end{array}$ & Military & Inward-looking; protectionist. \\
\hline 1979 & $\begin{array}{l}\text { Ft. Lt. J.J. Rawlings, Armed Forces } \\
\text { Revolutionary Council (AFRC) }\end{array}$ & Military & $\begin{array}{l}\text { Some reforms but a general tightening of economic } \\
\text { controls. }\end{array}$ \\
\hline 1979-1981 & Dr. Hilla Limann (PNP) & Civilian & No real change. \\
\hline 1981-1992 & $\begin{array}{l}\text { Fl. Lt. J.J. Rawlings, Provisional } \\
\text { National Defence Council (PNDC) }\end{array}$ & Military & $\begin{array}{l}\text { Initially a tightening of controls; from April 1983, } \\
\text { outward-oriented economic recovery programme } \\
\text { and adjustment (ERP). }\end{array}$ \\
\hline 1993-1996 & $\begin{array}{l}\text { Fl. Lt. J.J. Rawlings, National } \\
\text { Democratic Congress (NDC) }\end{array}$ & Civilian & $\begin{array}{l}\text { 4th Republic; continuation of ERP, privatisation and } \\
\text { divestiture; no regular opposition in Government/ } \\
\text { Parliament. }\end{array}$ \\
\hline $1997-2000$ & Fl. Lt. J.J. Rawlings (NDC) & Civilian & $\begin{array}{l}\text { 2nd Election, 4th Republic; minority parties } \\
\text { participate in election; market orientation. }\end{array}$ \\
\hline 2001-2008 & John Agyekum Kufuor (NPP) & Civilian & $\begin{array}{l}\text { Multi-party democracy (two terms), market } \\
\text { orientation. }\end{array}$ \\
\hline 2009-2012 & Prof. John Atta-Mills (NDC) & Civilian & Multi-party democracy; market orientation. \\
\hline 2013-2016 & John Dramani Mahama (NDC) & Civilian & Multi-party democracy; market orientation. \\
\hline Since 2017 & $\begin{array}{l}\text { Nana Addo Danquah Akufo Addo } \\
\text { (NPP) }\end{array}$ & Civilian & $\begin{array}{l}\text { Multi-party democracy; mixture of market } \\
\text { orientation and heavy social spending by } \\
\text { government. }\end{array}$ \\
\hline
\end{tabular}

Source: adapted from Fosu and Aryeetey (2017) 
was later restructured into the influential Ministry for Trade and Industry, Private Sector Development, and President's Special Initiatives (MOTI, PSD, and PSIs). Because the programme was so strongly associated with Kyeremanteng, other government agencies who were supposed to support it were either resistant or, like MoFA, "they hardly embraced the programme because the Ministry had not been [officially] invited to participate in PSIs" (Asante 2012: 28).

Its smooth functioning was also strongly influenced by the political clout of officials attached to it. The first National Coordinator of the PSI-Oil Palm was able direct mobilise funds from the President Kufuor's Chief of Staff, Kwadwo Mpiani, but his successor, who was much less influential and, unable to raise the funds needed to continue implementation, ended up merely "holding the fort" until the programme was eventually dissolved by Kyeremanteng (Asante 2019: 28).

When the NDC came back to power in 2009, MoFA commissioned a master plan for the development of the oil palm sector. The report, prepared by MASDAR, proposed seven different projects with a detailed implementation plan between 2012 and 2025. The proposed projects were 1) establishment of 10,000ha nucleus estate and 60tph mill plantation company; 2) 40,000ha Smallholders Development Scheme including a smallholder Services Entity and a Road Maintenance Fund; 3) Village Level Replanting Programme (110,000ha); 4) Small-Scale Mills Transformation Programme; 5) industrial palm oil-based manufacturing projects; 6) support services and industries; and 7) basic supportive infrastructure (MASDAR 2011: 7.1-2). However, this plan was not implemented. A high-ranking official at MoFA explained that funding constraints was a significant reason for the master plan not to materialise (interview with official of Tree Crop Services directorate of MoFA). But other respondents attributed the failure to implement the plan to the tendency for certain policy interventions to become too closely identified with the minister or politician who initiated them (officials at MoFA, pers. comm. March 2020), with the consequence that once they exit from office, their successors are not as keen to follow through with those policies.

When the NPP came back to power in 2017, MoFA launched a flagship programme called Planting for Food and Jobs. Launched on 19 April 2017, the policy is broadly aimed at job creation and poverty reduction in the agricultural sector by promoting food production, as well as a reduction of the country's food import bill (MoFA 2019a: 9). To achieve these goals, the programme is structured around 5 pillars, namely 1) subsidised improved seeds, 2) subsidised fertilisers, 3) reliable and routine technical assistance through extension services, 4) improving market linkages to abate price volatility, and 5) improved targeting and surveillance through the use of e-agriculture. Most of these pillars, specifically 1, 2, 4, and 5 would be built on a foundation of public-private partnership (MoFA 2017b: 13-14). The programme targeted seven food crops (maize, rice, sorghum, tomato, onion, chilli pepper, and soya bean) 'based on their contribution to national socioeconomic importance' (MoFA 2017: 18). The Planting for Food and Jobs campaign (PFJ) is intended to support the One District One Factory initiative, another ambitious plan of the government to accelerate industrialisation, by feeding factories with raw materials for downstream processing.

On 23 April 2019, the president launched PERD as a programme under the Tree Crop Module of PFJ, to be jointly implemented by MoFA and the Ministry of Local Government and Rural Development. The programme focuses on up to nine tree crops with historical or potential export records, namely cashew, coffee, oil palm, coconut, mango, citrus, cotton, shea, and rubber, in an effort to diversify the tree crop export sector away from cocoa (GoG [Government of Ghana], no date). However, each district is eligible to submit only two crops to be developed, after first making sure that the crops meet three crucial criteria of 1) ecological adaptability, 2) economic competitiveness, and 3) socio-cultural acceptability. At the beginning of each year, every district is expected to submit to its programme office the expected number of seedlings the district can raise (MoFA 2019b). Smallholder farmers are the main beneficiaries of the PERD programme, although the government plans to include some of the dominant players in executing some of the elements of the programme. For instance, in the Ahanta West Municipality, there is a planned partnership with Norpalm Ghana Limited to raise and supply farmers with improved seedlings.

Following the passage of the Tree Crop Development Act in December 2019, the tree crop sector is set to witness major changes. The act established the TCDA, which will be the governing body for the country's tree crops sub-sector. Stakeholders in the oil palm value chain had been lobbying for years for a national regulatory body of this sort, but the government decided to create a four-crop authority instead (executive of OPDAG, researchers at Solidaridad and ProForest, pers. comm. March 2020). Actors in the industrial use segment of the value chain and representatives of the artisanal segment, as well as NGOs active within it, have all expressed optimism that the TCDA will provide needed regulations (regarding issues like environmental impact and pricing) and help solve longstanding problems constraining growth in 
the industry (executives of executives of Artisanal Palm

Oil and OPDAG, pers comm. March and May 2020, and with researchers at Solidaridad and Proforest, and officials at MoFA, March and May 2020). The TCDA should have been operational by the end of the first quarter of 2020, but has been delayed owing to the disruptions caused by the COVID-19 pandemic. 
Ghana, like other countries, has undergone massive disruptions since recording its first two cases of COVID-19 on 12 March 2020. On 30 March 2020, three Ghanaian cities were placed under a partial lockdown for three weeks. Other restrictions on public gatherings continue to be in place, but on 31 May, the president announced a gradual easing of these restrictions, which would allow public gatherings of not more than 100 people. However, the country's borders remain closed. To mitigate the impact of the pandemic, the government announced the Coronavirus Alleviation Programme in May 2020, which provides a GH\$ 1 billion stimulus package for industry and citizens which aimed to, among other things, safeguard jobs, protect livelihoods, support small businesses, and promote selected industries. There is not yet a definite measure of the scale of the impact of the pandemic, and how different sectors of the economy have been affected. To contribute to filling this gap, this section draws on indepth interviews and a rapid market survey conducted in May and June 2020 to examine the impact of COVID-19 on the oil palm value chain.

The impact of the pandemic has affected the entire oil palm value chain. At the global level, weak demand and falling oil prices as a result of the pandemic led to falling world food prices (UN 2020). The FAO Vegetable Oil Price Index dropped from 139.0 points to 131.8 (5.2 per cent) between March and April 2020. The international price of CPO has consistently declined during the pandemic - from US\$730/t in January 2020 to US\$550/t in April (Asian Crude Palm Oil Watch 1Q20 2020) - because weak demand was exacerbated by production from Malaysia exceeding initial projections (FAO 2020).

The impact of the drop in world market prices have been felt most directly by the estates who engage directly on the world market, but other actors along the chain have also been affected. These companies, who participate directly in the global market, were compelled to substantially reduce operations. They could no longer afford to buy FFBs because of the drop in world prices for CPO, leading to a drop in farmgate prices (executive of Artisanal Palm Oil, pers. comm. May 2020). Even so, Wilmar was the only company able to buy CPO (interview with executive of OPDAG, May 2020). This slow-down also affected transporters of CPO, who had to queue for days before offloading, owing to pressure on Wilmar as the sole buyer (executive of OPDAG, pers. comm. May 2020).

In addition to falling prices of FFBs, access to both local and regional markets have been severely constrained. With regards to the local market, restrictions on public gatherings and closure of eateries decreased demand for palm oil, resulting in a price reduction. In May 2020, a $25 \mathrm{~kg}$ gallon of oil was sold at $\mathrm{GH} \$ 55$, a reduction from the pre-pandemic price of about $\mathrm{GH} \$ 80$. The closure of schools has also seriously affected small millers who, since the introduction of the current government's Free Senior High School policy, had enjoyed constant demand for their products (rapid market survey, May and June 2020; executive of Artisanal Palm Oil, pers. comm. May 2020).

The estates and better-resourced actors in the artisanal segment of the value chain are also no longer able to access the sub-regional market because of border closures as a measure to restrict the spread of the virus (rapid market survey, May and June 2020; executive of Artisanal Palm Oil, pers. comm. May 2020). Even though Nigerian land borders had been closed since August 2019 in order to prevent the smuggling of rice (Orjinmo 2019), the estates were still able to access the Nigerian market by channelling exports through the ports, a situation which is now impossible due to COVID-19 related restrictions (executive of OPDAG, pers. comm. May 2020).

Data from the rapid market survey suggests that the impact of the pandemic on labour arrangements along the chain appears mixed. The agri-businesses surveyed had a minimum of 17 and maximum of 150 workers, and although some had been compelled to lay-off up to three-quarters of employees because of reduced operations, others were struggling to meet their labour needs. Labour shortage is a result of the importance of migrants as farm workers. A combination of movement restrictions, and fear of contracting the virus by commuting, markedly reduced the flow of migrant workers. However, one respondent reported that because many workplaces are now closed, he has access to a pool of labour that 
was otherwise employed, or hitherto unwilling to take up on-farm employment.

Farmers and processors along the chain have been forced to substantially scale down on production, with many reducing the amounts of inputs they sourced by at least a half. For instance, an artisanal miller who used to source between $35 \mathrm{t}$ and $40 \mathrm{t}$ of FFBs a week was now getting not more than 16t. The revenue losses are also equally substantial, from a minimum of $\mathrm{GH} \$ 4,000$ to as much as $\mathrm{GH} \$ 400,000$.

To survive, they have resorted to a variety of measures, including scaling down production and storing processed palm oil (but this is a lot more difficult for poorer millers for whom ability to quickly sell is key to their survival). Others are, however, exploring new businesses opportunities, such as soap production, or leveraging on social media and highlighting delivery services to market their products.

As part of government's COVID-19 alleviation package, the National Board for Small Scale Industries (NBSSI) has introduced a GH\$ 600 million stimulus package for small and medium enterprises. The leadership of the association for artisanal millers has approached NBSSI for assistance on behalf of members (executive of Artisanal Palm Oil, pers. comm. May 2020). However, stakeholders would like to see more substantial support from the government. For instance, an OPDAG executive remains unimpressed with the stimulus package of GH\$600 million introduced by government to assuage the impact on small and medium enterprises (SME):

"They said they have about 200,000 companies or SMEs that are going to benefit from that package. So, using our maths that means each SME is going to get an amount of $\mathrm{GH} \$ 3000$. And GH\$3000 in an oil palm sector, I think it is nothing" (executive of OPDAG, pers. comm. May 2020).

Accordingly, OPDAG has started engagements with officials at NBSSI for more substantial assistance. According to the interviewed OPDAG executive:

"The amount the oil palm sector needs for reallocation, it's in hundreds of thousands, not tens of thousands. If you really want to save the sector in this pandemic, the amount mentioned by the government as a stimulus package, we think it is not enough".

However, other players admit that government is already under severe fiscal constraints and cannot realistically do much more than it is currently doing" (GOPDC manager, pers comm. May 2020).
The pandemic also affected the timeline for the launch of the much-anticipated TCDA. It shifted the attention of policymakers to managing the impact of the pandemic. A committee set up to operationalise the implementation of the act that set up the authority was submitted to the sector minister in March, for onward transmission to cabinet for approval. The president was originally supposed to have launched the authority in June. However, at the beginning of June, the committee's report had yet to undergo cabinet consideration, partly because the government was almost exclusively focused on fighting the pandemic and did not seem to be in a position to give the about GH\$ 5 million initial amount necessary to operationalise the TCDA. The authority was finally inaugurated on 29 September 2020, and during the ceremony the president underscored the need to prioritise the cash crop sector. He believed that by strengthening the link between agriculture and industry, his agricultural policies would 'develop our rural economies, and assist in the structural transformation of the national economy. All these will propel growth, create employment, particularly for the youth, and the creation of wealth' (GOG 2020). 
Oil palm is one of the most important crops in Ghana. It played a crucial role in the transition from the slave trade to legitimate commerce in West Africa, made substantial contributions to the revenue of the Gold Coast colonial government, and since independence, has featured prominently in the development agenda of successive Ghanaian governments. However, the sector has continued to underperform in spite of its strategic importance to the economy and the sustained policy attention devoted to it. To explain this paradoxical outcome, this paper has shown how attempts to develop the oil palm value chain is constrained by political economy factors, such as land tenure arrangements and the competitive clientelist political settlement that shapes the way policies are formulated in the country. In particular, insecure access to land continues to restrict the ability of estates to expand their plantations and forces them to rely on smallholders. Moreover, because of their weak position in the country's political settlement, the industrial segment of the value chain continues to be neglected in resource allocation in spite of the government's own rhetorical commitment to industryled economic growth.

Efforts to revive the sector have yielded little results because they have insufficiently dealt with the complex organisation of the value chain. Even though the value chain has two separate segments with their own internal organisation, actors in the separate segments sometimes overlap, creating problems arising from clashing interests and unequal access to power and resources. For instance, estate mills are compelled to source FFBs from independent smallholder farmers to make up for the shortfall in their plantation output. However, independent smallholders have very little incentives to comply with the rigorous quality standards of the estates, because the home-consumption market provides them with an alternative outlet for their produce. Moreover, independent smallholders are resistant to attempts to reduce prices in response to fluctuations on the world market. This became especially problematic during the COVID-19-induced lockdowns, which halted international trade for much of 2020 and led to a sharp decline in the price of CPO.
Recent policies have not effectively addressed the segmented nature of the value chain, even though the success of policies targeting the sector is dependent on the cooperation of both segments. This problem is exacerbated by two aspect of the multiparty system, namely:

- a rhetorical commitment to poverty reduction and economic transformation; and

- the logic of electoral competition, which predisposes government officials to focus on short-term political calculations.

The focus on poverty reduction has motivated the policy strategy of targeting smallholders with inputs like seedlings and fertilisers. However, poor supporting infrastructure, weak marketing systems, and inadequate industry-wide integration continue to frustrate such efforts. At the same time, political leaders prefer the distribution of targeted goods to smallholders because of its potential electoral payoffs. Consequently, it is extremely difficult to end such programmes even when they fail to yield desired outcomes. Within this political context, policymakers are reluctant to make tough but necessary decisions regarding the sector or to stick to such decisions once they are made. As a result, policies designed to promote growth in the oil palm industry have failed to resolve the longstanding structural barriers to productivity. The consequence is that after a century and a half of more or less sustained policy attention, the sector is as productive as it would have been had it been left to operate on its own. 


\section{REFERENCES}

Adjei-Nsiah, S.; Sakyi-Dawson, O. and Kuyper, T.W. (2012) 'Exploring Opportunities for Enhancing Innovation in Agriculture: The case of oil palm production in Ghana', Journal of Agricultural Science 4.10: 212-223

Amanor, K.; Yaro, J. and Teye, J. (2020) Long-Term Change and Agricultural Commercialisation in Ghanaian Cocoa, APRA Working Paper 31, Brighton: Future Agricultures Consortium

Amarteifio, W. (2020) 'Ameen Sangari Closed Down by Management After Staff Protest', Prime News Ghana, 2 March 2020 (accessed 30 October 2020)

Ambassade de France au Ghana (2015) AFD and ADB signed a financial agreement for the Rubber Outgrower Plantation Project, Ambassade de France au Ghana website, https://gh.ambafrance.org/AFD-and-ADB-signeda-financial-agreement-for-the-Rubber-Outgrower-Plantation (accessed 30 May 2020)

Appiah, D. and Abdulai, A.-G. (2017) Competitive Clientelism and the Politics of Core Public Sector Reform in Ghana, ESID Working Paper No. 82, Manchester: Global Development Institute

Appiah-Kubi, K. (2001) 'State-Owned Enterprises and Privatisation in Ghana', The Journal of Modern African Studies 39.2: 197-229

Asante, E.A. (2012) The Case of Ghana's President's Special Initiative on Oil Palm (PSI-oil palm), DIIS Working Paper 2012: 11, Copenhagen: Danish Institute for International Studies

Asante, K.T. (2018) "IIntimate Knowledge of the Country": Factionalism in the Mid-Nineteenth-Century Gold Coast Administration', African Economic History 46.2: 63-92

Asante, K.T. (2019) 'Nested Patriotism: Revisiting Collaboration, Resistance and Agency in Colonial Ghana', International Journal of Politics, Culture, and Society 33.3: 347-364

Asante, K.T. and Khisa, M. (2019) 'Political Corruption and the Limits of Anti-Corruption Activism in Ghana', in I. Amundsen (ed.), Political Corruption in Africa, Cheltenham: Edward Elgar Publishing

B\&FT (Business and Financial Times) (2020) 'Local Oil Palm Producers Hail 50\% Benchmark Value Exemption', B\&FT Online, 19 May 2020, (accessed 30 May 2020)

Banful, A.B. (2009) Operational Details of the 2008 Fertilizer Subsidy in Ghana-Preliminary Report, Ghana Strategy Support Programme (GSSP) Background Paper 18, Accra: International Food Policy Research Institute

Banful, A.B. (2011) 'Old Problems in the New Solutions? Politically Motivated Allocation of Program Benefits and the "New" Fertilizer Subsidies', World Development 39.7: 1166-1176

Behuria, P. (2020) 'The Domestic Political Economy of Upgrading in Global Value Chains: How Politics Shapes Pathways for Upgrading in Rwanda's Coffee Sector', Review of International Political Economy, 27.2: 348-376

Bentil, N.L. (2019) 'GOPDC Calls on Government to Review Benchmark Valuation’ Daily Graphic, 15 July 2019, (accessed 30 May 2020)

Boafo-Arthur, K. (1999) 'Ghana: Structural Adjustment, Democratization, and the Politics of Continuity', African Studies Review 42.2: 41-72

Castellanos-Navarrete, A. and Jansen, K. (2018) 'Is Oil Palm Expansion a Challenge to Agroecology? Smallholders Practising Industrial Farming in Mexico', Journal of Agrarian Change 18.1: 132-155 
Donovan, J. et al. (2015) 'Guides for Value Chain Development: A Comparative Review', Journal of Agribusiness in Developing and Emerging Economies 5.1: 2-23

Dummet, R.E. (1983) 'African Merchants of the Gold Coast, 1860-1905, Dynamics of Indigenous Entrepreneurship', Comparative Studies in Society and History 25.4: 661-693

Dzanku, F.M. et al. (2020) Smallholder Farmers' Choice of Oil Palm Commercialisation Model and Household Welfare in South-western Ghana, Working Paper 43, Brighton: Future Agricultures Consortium

Dzanku, F.M. and Hodey, L.S. (2019) Oil Palm Commercialisation Models and Outcomes in South-Western Ghana, unpublished research report, Brighton: Institute of Development Studies

FAO (2005) Fertilizer Use by Crop in Ghana, Rome: Food and Agriculture Organization of the United Nations

FAO (2020) FAO Food Price Index (accessed 4 June 2020)

Fitchratings (2020) Asian Crude Palm Oil Watch 1Q20 (accessed 4 June 2020)

Fold, N. and Whitfield, L. (2012) Developing a Palm Oil Sector: The Experiences of Malaysia and Ghana Compared, DIIS Working Paper 2012: 08, Copenhagen: Danish Institute for International Studies

Fosu, A. and Aryeetey, E. (2017) 'The Importance of Political Economy and Ghana’s Post-Independence Economic Growth Performance', in F. A. Asante, R. Osei, and G. Owusu (eds), Development Policies and Practices in Ghana: A Reader, Accra: Institute of Statistical, Social and Economic Research

GOG (2020) 'President Akufo-Addo Inaugurates Tree Crop Development Authority; Headquarters in Kumasi', The Presidency, Republic of Ghana, 29 September 2020 (accessed 30 October 2020)

GOG (no date) Medium Term Expenditure Framework (MTEF) for 2019-2022. Ministry of Food and Agriculture: Programme Based Budget Estimates for 2019, Accra: Government of Ghana

GSS (2012) 2010 Population and Housing Census: Final Results, Accra: Ghana Statistical Service

GSS (2019) Ghana Living Standards Survey (GLSS) 7: Main Report, Accra: Ghana Statistical Service

Gyasi, E.A. (1992) 'Emergence of a New Oil Palm Belt in Ghana', Tijdschrift Voor Economische en Sociale Geografie 83.1: 39-49

Heerink, N.; Atsma, P. and Fosu, K.Y. (1997) 'Farmers' Transport Costs and Agricultural Production in Ghana', in W.K. Asenso-Okyere,; G. Benneh and W. Tims (eds), Sustainable Food Security in West Africa, New York: Springer International Publishing

Hickey, S. (2013) Thinking About the Politics of Inclusive Development: Towards a Relational Approach', ESID Working Paper No. 1, Manchester: Global Development Institute

Hickey, S. and Du Toit, A. (2013). 'Adverse Incorporation, Social Exclusion, and Chronic Poverty', In A. Shepherd and J. Brunt (eds), Chronic Poverty, London: Palgrave Macmillan

Huddleston, P. and Tonts, M. (2007) 'Agricultural Development, Contract Farming and Ghana's Oil Palm Industry', Geography 92.3: 266-278

ISSER (2019) The State of the Ghana Economy in 2018, Accra: Institute of Statistical, Social and Economic Research

Johnson, T.J. (1972) 'Protest: Tradition and Change: An Analysis of Southern Gold Coast Riots 1890-1920', Economy and Society 1.2: 164-193

Khan, M.H. (2005) 'Markets, States and Democracy: Patron-Client Networks and the Case for Democracy in Developing Countries', Democratisation 12.5: 704-724

Khan, M.H. (2018) 'Political Settlements and the Analysis of Institutions', African Affairs, 117.469: 636-655

Khatun, K. et al. (2020) 'From Agroforestry to Agroindustry: Smallholder Access to Benefits from Oil Palm in Ghana and the Implications for Sustainability Certification', Frontiers in Sustainable Food Systems 4: 1-13 
Kimble, D. (1963) A Political History of Ghana: the Rise of Gold Coast Nationalism, 1850-1928, Oxford: Clarendon Press

Law, R. (1995) 'Introduction', in R. Law (ed), From Slave Trade to 'Legitimate' Commerce: The Commercial Transition in Nineteenth Century West Africa, Cambridge: Cambridge University Press

Manley, R. and Van Leynseele, Y. (2019) 'Peasant Agency in Ghana's Oil Palm Sector: The Impact of Multiple Markets on Food Sovereignty', Journal of Agrarian Change 19.4: 654-670

MASDAR (2011) Master Plan Study for the Oil Palm Industry in Ghana: Final Report, Accra: Ministry of Food and Agriculture

MoFA (2017a) Agriculture in Ghana: Facts and Figures (2016), Accra: Ministry of Food and Agriculture

MoFA (2017b) Planting for Food and Jobs: Strategic Plan for Implementation (2017-2020), Accra: Ministry of Food and Agriculture

MoFA (2019a) Ministry of Food and Agriculture Operational Performance (2017-2018), Accra: Ministry of Food and Agriculture

MoFA (2019b) 'Planting for Export and Rural Development in the Ahanta West Municipality: Concept Note', Accra: Ministry of Food and Agriculture

MoFA (no date), 'Programme for the Promotion of Perennial Crops in Ghana, Accra: Ministry of Food and Agriculture (accessed 30 May 2020)

Ofosu-Budu, K. and Sarpong, D. (2013) 'Oil Palm Industry Growth in Africa: A Value Chain and Smallholders' Study for Ghana', in A. Elbehri (ed), Rebuilding West Africa's Food Potential, Rome: FAO/IFAD

OPDAG (no date) 'History and Background', Accra: Oil Palm Development Association of Ghana (accessed 30 May 2020)

Opoku, J. and Asante, F.A. (2008) Palm Oil Production in Ghana, Final report on the status of the oil palm industry in Ghana submitted to GTZ, Accra: German Technical Co-operation

Orjinmo, N. (2019) 'Nigeria's Border Crisis Fuelled by Rice', BBC News, 31 October (accessed 30 May 2020)

Osei-Amponsah, C. (2013) Improving the Quality of Crude Palm Oil: Transdisciplinary Research on Artisanal Processing in Kwabibirem District, Ghana, PhD dissertation, Wageningen: Wageningen University

Osei-Amponsah, C. et al. (2012) 'Processing Practices of Small-Scale Palm oil producers in the Kwaebibirem District, Ghana: A Diagnostic Study', NJAS-Wageningen Journal of Life Sciences 60: 49-56

Osei-Amponsah, C. et al. (2014) 'Institutional Change and the Quality of Palm Oil: An Analysis of the Artisanal Processing Sector in Ghana', International Journal of Agricultural Sustainability 12.3: 233-247

Prowse, M. and Moyer-Lee, J. (2014) 'A Comparative Value Chain Analysis of Smallholder Burley Tobacco Production in Malawi-2003/4 and 2009/10', Journal of Agrarian Change 14.3: 323-346

Resnick, D. (2016) Strong Democracy, Weak State: The Political Economy of Ghana's Stalled Structural Transformation, IFPRI Discussion Paper 01574, Accra: International Food Policy Research Institute

Ruml, A. and Qaim, M. (2020) 'Smallholder Farmers' Dissatisfaction with Contract Schemes in Spite of Economic Benefits: Issues of Mistrust and Lack of Transparency', The Journal of Development Studies, (accessed 30 October 2020)

Shepherd, A. (2016) Including Small-Scale Farmers in Profitable Value Chains: Review of Case Studies on Factors Influencing Successful Inclusion of Small Farmers in Modern Value Chains in ACP Countries, Wageningen: Technical Centre for Agricultural and Rural Co-operation (CTA)

Tangri, R. (1992) 'The Politics of Government-Business Relations in Ghana', The Journal of Modern African Studies 30.1: 97-111 
Teye, K.J. and Torvikey, G.D. (2018) The Political Economy of Agricultural Commercialisation in Ghana: A Review, APRA Working Paper 15, Brighton: Future Agricultures Consortium

Tsikata, D. and Yaro, J.A. (2013) 'When a Good Business Model is Not Enough: Land Transactions and Gendered Livelihood Prospects in Rural Ghana'. Feminist Economics 20.1: 202-226

UN (2020) World food Prices Drop in March due to COVID-19 and Oil - Africa Renewal, New York: United Nations (accessed 4 June 2020)

Whitfield, L. (2011a) Competitive Clientelism, Easy Financing and Weak Capitalists: The Contemporary Political Settlement in Ghana, DIIS Working paper 2011: 27, Copenhagen: Danish Institute for International Studies

Whitfield, L. (2011b) Growth Without Economic Transformation: Economic Impacts of Ghana's Political Settlement, DIIS Working Paper 2011: 28, Copenhagen: Danish Institute for International Studies

Wilson, L.E. (1990) 'The "Bloodless Conquest" in Southeastern Ghana: The Huza and Territorial Expansion of the Krobo in the 19th Century', The International Journal of African Historical Studies 23.2: 269-297

Yaro, J.A.; Teye, J.K. and Torvikey, G.D. (2018) 'Historical Context of Agricultural Commercialisation in Ghana: Changes in Land and Labour Relations', Journal of Asian and African Studies 53.1: 49-63 


\section{APPENDIX: GROSSCUTTINGG HYPOTHEESES}

\section{Appendix 1: Hypothesis one}

Even though Ghana is a coastal country, urbanisation did not have a direct impact on oil palm production and commercialisation. Before the early nineteenth century, oil palm was cultivated on a small-scale or harvested in the wild for domestic consumption, and matured trees were felled to brew palm wine. Commercialisation of oil palm and other agricultural commodities commenced in the wake of the abolition of the slave trade and the emergence of the so-called legitimate commerce (see above). Throughout the nineteenth century, production of palm remained in the hands of farmers in the immediate hinterlands of the coastal cities, but the coastal African elite acted as intermediaries between the producers and the international market. Throughout this period, the oil palm industry thrived without the active intervention of the colonial government. The decline of palm oil production and export begun after the world market price sharply declined at the end of the nineteenth century, prompting farmers to reallocate their lands for cocoa cultivation. Cocoa had grown to become the colony's leading export commodity by the beginning to the twentieth century. When Ghana attained independence in 1957, the country had become a net palm oil importer and attempts by successive governments to promote the industry yielded weak results. Currently, competition from imports make local production uncompetitive. Local producers have continuously petitioned government to exempt imported edible oils from reduction in benchmark prices. However, they have so far been unsuccessful because of countermeasures taken by the traders' association who have an interest in keeping imported edible oil prices low.

\section{Appendix 2 Hypothesis two}

\section{Not applicable}

\section{Appendix 3: Hypothesis three}

Palm oil export was the leading source of foreign exchange for the colonial regime in the nineteenth century. However, since the beginning of the twentieth century, its contribution to foreign exchange for the country has been negligible. On the contrary, as a net importer, the country spends foreign exchange to make up for the domestic deficit in production. As a result, policies designed for the industry have been motivated by the need to reduce the country's palm oil import bill. In spite of the importance of this objective, the clientelist logic of electoral competition have presented obstacles in the way of successful implementation of policies designed to promote the industry. Moreover, ruling elites attempt to use elements of these policies, such as input subsidies, to secure the loyalty of rural populations.

\section{Appendix 4: Hypothesis four}

Smallholder farmers dominate the cultivation of oil palm in Ghana even though production occurs in sub-national regions with low population density. Data from the 2010 Population and Housing Census shows generally low population densities in producing regions in 2010, and much lower in the preceding decades (see Table 5). Indeed, the Eastern Region, with the largest land area under cultivation has a population density of 136 persons/sq km, and the region with the second largest area under cultivation has a population density of only 99 persons/sq km. Out of the six producing regions, only Central Region, has a high population density (>200 persons $/ \mathrm{sq} \mathrm{km).} \mathrm{Medium-} \mathrm{and} \mathrm{large-scale} \mathrm{farms} \mathrm{have} \mathrm{been} \mathrm{active} \mathrm{for} \mathrm{decades} \mathrm{in} \mathrm{the} \mathrm{value} \mathrm{chain} \mathrm{but} \mathrm{have} \mathrm{been}$ unable to significantly expand their production - irrespective of the population density in their region of operation - owing to the complicated nature of land acquisition and the relative absence of litigation-free land. 
Table A1 Population densities in oil palm growing areas

\begin{tabular}{|l|l|l|l|l|}
\hline \multirow{2}{*}{ Region } & Area under cultivation (in & \multicolumn{3}{|l|}{ Population Density (no. of persons/sq km) } \\
\cline { 3 - 5 } & per cent) & 1984 & 2000 & 2010 \\
\hline Ashanti & 10 & 86 & 148 & 196 \\
\hline Brong Ahafo & 10 & 31 & 46 & 58 \\
\hline Central & 16 & 116 & 162 & 224 \\
\hline Eastern & 32 & 87 & 109 & 136 \\
\hline Volta & 4 & 59 & 80 & 103 \\
\hline Western & 28 & 48 & 80 & 99 \\
\hline
\end{tabular}

Source: Author's construct using data from the 2010 Population and Housing Census (GSS 2012)

\section{Appendix 5: Hypothesis five}

Development partners have been engaged to attempts to promote the value chain for decades. In the 1980s, when the country begun implementing the structural adjustment programme, policies were developed to promote the direct participation of the private sector in the value chain. As a result, government offloaded most of its interests in the state-ran plantations and mills. Since the 2000s, policy interventions in the value chain explicitly incorporate poverty reduction and livelihood empowerment goals through interventions like input subsidies, market linkages, and rural infrastructural development. The policy shifts have largely coincided with the dominant views in the international donor community. 
Asante, K.T. (2021) The Political Economy of the Oil Palm Value Chain in Ghana, APRA Working Paper 54, Brighton: Future Agricultures Consortium

(c) APRA 2021

ISBN: 978-1-78118-787-6

DOI: 10.19088/APRA.2021.008

\section{(cc) BY-NC-ND}

This is an Open Access report distributed under the terms of the Attribution-Non Commercial-No Derivs 4.0 Unported (CC BY-NC-ND 4.0) Attribution - You must give appropriate credit, provide a link to the license, and indicate if changes were made. You may do so in any reasonable manner, but not in any way that suggests the licensor endorses you or your use. NonCommercial — You may not use the material for commercial purposes. NoDerivatives - If you remix, transform, or build upon the material, you may not distribute the modified material. You are free to: Share - copy and redistribute the material in any medium or format.

https://creativecommons.org/licenses/by-nc-nd/4.0/legalcode

If you use the work, we ask that you reference the APRA website (www.future-agricultures.org/apra/) and send a copy of the work or a link to its use online to the following address for our archive: APRA, Future Agricultures Consortium, University of Sussex, Brighton BN1 9RE, UK (apra@ids.ac.uk)

All APRA Working Papers go through a review process before publication.

\section{@creative}

DO YOU HAVE COMMENTS ON THIS PAPER?

We would welcome your feedback on this working paper!

To provide brief comments, please follow this link to our short APRA Working Paper Feedback form: https://goo.gl/forms/1iVnXhhrlGesfR9

Agricultural Policy Research in Africa (APRA) is a programme of the Future Agricultures Consortium (FAC) which is

generating new evidence and policy-relevant insights on more inclusive pathways to agricultural commercialisation in sub-Saharan Africa. APRA is funded with UK aid from the UK Foreign, Commonwealth \&

Development Office (FCDO) and will run from 2016-2022.

The APRA Directorate is based at the Institute of Development Studies (IDS), UK (www.ids.ac.uk), with regional hubs at the Centre for African Bio-Entrepreneurship (CABE), Kenya, the Institute for Poverty, Land and Agrarian Studies (PLAAS), South Africa, and the University of Ghana, Legon. It builds on more than a decade of research and policy engagement work by the Future Agricultures Consortium (www.future-agricultures.org) and involves more than 100 researchers and communications professionals in Africa, UK, Sweden and USA. 